\title{
De waarheidsplicht en de geraden gevolgtrekking anno 2020: een zoektocht naar proportionaliteit
}

\author{
Cindy Seinen*
}

\begin{abstract}
1 Inleiding
Wanneer een procespartij de waarheidsplicht schendt, kan de rechter daaruit de gevolgtrekking maken die hem geraden voorkomt. ${ }^{1}$ Die discretionaire bevoegdheid tot toetsen en sanctioneren heeft de rechter ambtshalve. Een verrassingsbeslissing levert gebruik ervan niet op, tenzij partijen gezien het partijdebat met een dergelijke beslissing en de gevolgen daarvan geen rekening hoefden te houden. ${ }^{2}$ Rechters hebben dus veel vrijheid bij het sanctioneren van de waarheidsplicht; ${ }^{3}$ vrijheid die de wetgever heeft toegekend omwille van het maatschappelijk belang dat rechterlijke beslissingen zo veel mogelijk berusten op de materiële waarheid. ${ }^{4}$ Wel moeten sancties in overeenstemming zijn met de aard en de ernst van de schending. ${ }^{5}$ In mijn bijdrage uit $2014^{6}$ inventariseerde ik de gevolgtrekkingen die rechters aan verschillende soorten schending verbonden. Inmiddels komt de waarheidsplicht in procedures nog vaker aan de orde, ofwel omdat een partij om sanctionering ervan vraagt, dan wel omdat de rechter ambtshalve oordeelt dat sanctionering nodig is. Omdat de creativiteit bij zowel het vragen als het opleggen van sancties sinds 2014 lijkt
\end{abstract}

Mr. C.J-A. Seinen is rechter in de rechtbank Den Haag en buitenpromovenda aan de Vrije Universiteit Amsterdam.

1. Art. 21, 22 lid 4, 88 lid 2, 162 lid 2, 164 lid 3, 179 lid 4, 196 lid 2 en 198 lid 3 en 4 Rv.

2. HR 25 maart 2011, ECLI:NL:HR:2011:BO9675, JPF 2011/85, NJ 2012/627, m.nt. H.J. Snijders, r.o. 3.3; HR 18 november 2011, ECLI:NL:HR:2011:BS1706, RvdW 2011/1422, r.o. 3.5.1.

3. HR 6 juli 2018, ECLI:NL:HR:2018:1103, NJ 2019/118, m.nt. S.D. Lindenbergh, r.o. 3.3.2.

4. Kamerstukken II 1999/2000, 26855, nr. 5, p. 25. Zie over het belang van waarheidsvinding uitgebreid R.H. de Bock, Tussen waarheid en onzekerheid: over het vaststellen van feiten in de civiele procedure (diss. Tilburg; Burgerlijk Proces \& Praktijk nr. 11), Deventer: Kluwer 2011, par. 2.

5. HR 25 maart 2011, ECLI:NL:HR:2011:BO9675, r.o. 3.3; HR 18 november 2011, ECLI:NL:HR:2011:BS1706, r.o. 3.5.1.

6. C.J-A. Seinen, 'De gevolgtrekking die hij geraden acht. Sancties op schending van de waarheidsplicht', TCR 2014, afl. 3, p. 84-95. toe te nemen, ${ }^{7}$ bespreek ik de ontwikkelingen dit keer niet aan de hand van de soorten schending van de waarheidsplicht, ${ }^{8}$ maar aan de hand van de typen gevolgtrekking die rechters aan schendingen hebben verbonden.

In deze bijdrage schets ik eerst enkele voor de sanctionering relevante aspecten van de waarheidsplicht (par. 2), om vervolgens in te gaan op de verschillende soorten gevolgtrekkingen die rechters daaraan verbinden - inclusief de vraag onder welke omstandigheden die gevolgtrekkingen proportioneel zijn (par. 3). Ik sluit af met een conclusie (par. 4).

\section{Enkele voor sanctionering relevante aspecten}

\subsection{Wat houdt de waarheidsplicht in?}

Procespartijen zijn op grond van art. $21 \mathrm{Rv}$ verplicht om alle voor de gevraagde beslissing relevante informatie volledig en waarheidsgetrouw aan te voeren: de gronden die tot toe- of afwijzing leiden, de stellingen die de gronden onderbouwen én de bescheiden waaruit de juistheid van die stellingen volgt. ${ }^{9}$ Daarbij is de vraag niet of (is bewezen dat) een partij een feit en de relevantie ervan kende, maar of zij die had behoren te kennen. Opzet is dus niet vereist om van een schending van de

7. Aanduidingen van frequentie in deze bijdrage zijn gebaseerd op de lijst met 972 uitspraken gedaan tussen 1 januari 2002 en 18 maart 2020 die ik via de zoekwoorden 'waarheid", substantiëringsplicht, $21 \mathrm{Rv}, 111 \mathrm{Rv}$, $128 \mathrm{Rv}^{\prime}$ vond op Rechtspraak.nl, LegalIntelligence.com en Google.com. Vooral in eerste aanleg worden uitspraken door een gebrek aan menskracht (voor o.m. anonimisering) maar mondjesmaat gepubliceerd. Mijn zicht op hetgeen niet is gepubliceerd, is beperkt; onzeker is daarom in hoeverre de uitspraken op mijn lijst representatief zijn voor de algemene praktijk.

8. De typen schending die ik in TCR 2014, afl. 3 onderscheidde, blijven bruikbaar.

9. Kamerstukken II 1999/2000, 26855, nr. 3, p. 52-53; Hof 's-Hertogenbosch 2 augustus 2011, ECLI:NL:GHSHE:2011:BR4259, r.o. 3.11; Rb. Dordrecht 7 december 2011, ECLI:NL:RBDOR:2011:BU6952; Rb. Zutphen 28 december 2011, ECLI:NL:RBZUT:2011:BV0742, r.o. 5.2; Rb. Limburg (ktr. Maastricht) 12 augustus 2015, ECLI:NL:RBLIM: 2015:6948, r.o. 3.3. Vgl. art. 18c Rv Cariben. 
waarheidsplicht te kunnen spreken; ${ }^{10}$ anderzijds kwalificeren kennelijke fouten en juridische miskwalificaties niet als schending indien de juiste stelling eenvoudig uit het stuk zelf blijkt. ${ }^{11}$

De maatstaf waaraan de rechter het gedrag van procespartijen afmeet, is of zij zich voldoende hebben verdiept in de context van hun zaak en in de vraag of de feiten die hun voor ogen staan wel kloppen en volledig zijn. Het doel van deze gedeeltelijke objectivering van de waarheidsplicht is enerzijds om partijen aan te zetten tot maatschappelijk zorgvuldig procederen ${ }^{12}$ en anderzijds om procedures niet te doen verzanden in bewijsperikelen over het al dan niet bestaan van opzet tot het onvolledig of onjuist informeren van de rechter (een 'procedure in de procedure'13).

Deelaspecten van de waarheidsplicht worden elders in de wet uitgewerkt. Zo moeten partijen:

- de stukken waarop zij zich beroepen onmiddellijk bij hun eerste processtuk voegen; ${ }^{14}$

- ter zitting verschijnen, op vragen van de rechter antwoorden en het proces-verbaal van het ter zitting verhandelde ondertekenen; ${ }^{15}$

- de gronden waarop hun eis of verzoek is gebaseerd vermelden; ${ }^{16}$

- de verweren van de wederpartij en de gronden daarvoor vermelden ('substantiëringsplicht'), alsmede de bewijsmiddelen waarover zij kunnen beschikken en de getuigen die zij kunnen doen horen ter staving van de betwiste gronden van hun eis ('bewijsaandraagplicht'); ${ }^{17}$

- de gronden voor hun eigen verweren vermelden, met de bewijsmiddelen waarover zij kunnen beschikken en de getuigen die zij kunnen doen horen ter staving van die verweren; ${ }^{18}$

- op bevel van de rechter de boeken, bescheiden en geschriften openleggen die zij op grond van de wet moeten houden, maken of bewaren; ${ }^{19}$

- als partij en/of partijgetuige ter zitting verschijnen, antwoorden op gestelde vragen en de eigen verklaring ondertekenen; ${ }^{20}$

- meewerken aan een onderzoek door deskundigen, ${ }^{21}$ waaronder betaling van het voorschot; ${ }^{22}$

- meewerken aan een plaatsopneming door de rechter; ${ }^{23}$

- zich in het geding onthouden van bedrog en valsheid in geschrifte; ${ }^{24}$

- stukken van beslissende aard niet achterhouden noch doen achterhouden. ${ }^{25}$

Uit jurisprudentie over de reikwijdte van de waarheidsplicht volgt verder dat procespartijen alle voor de beslissing relevante feiten uit eigen beweging ${ }^{26}$ moeten aanvoeren, ook als die feiten nadelig zijn voor hun eigen positie. ${ }^{27}$ Ter voorkoming van misverstand: ook het ontkennen van feiten waarvan men weet
10. Zie bijv. HR 15 september 2017, ECLI:NL:HR:2017:2360, JBPr 2018/3, m.nt. P.M. Vos, JIN 2017/180, m.nt. E.J.H. Zandbergen en J.H.L. Damen, NJ 2018/165, m.nt. S.D. Lindenbergh (Schilderij Koekkoek), r.o. 5.3.4 ('behoren'; 'moest begrijpen'); Hof 's-Hertogenbosch 10 december 2019, ECLI:NL:GHSHE:2019:4470, r.o. 3.9.3; Rb. Overijssel (vzr. Zwolle) 26 april 2019, ECLI:NL:RBOVE:2019:1462, r.o. 4.6.

11. Hof Arnhem-Leeuwarden (zittingsplaats Leeuwarden) 8 september 2015, ECLI:NL:GHARL:2015:6637, r.o. 3.9.

12. Kamerstukken II $1999 / 2000,26855$, nr. 3, p. 52; Kamerstukken II 1999/2000, 26855, nr. 5, p. 27. Vgl. HR 4 oktober 1996, ECLI:NL:HR: 1996:ZC2162, NJ 1998/45 (Goosen/Goosen), r.o. 3.3; HR 19 december 2003, ECLI:NL:HR:2003:AN7890, NJ 2005/181, m.nt. H.J. Snijders, r.o. 3.7; T.F.E. Tjong Tjin Tai, 'Rechterlijke discretie voor de privaatrechtelijke reactie op ongewenst gedrag', $M v V 2017$, afl. 7-8, par. 6 .

13. Zie o.m. Kamerstukken I 2001/02, 26855, nr. 16, p. 20; Handelingen I 2001/02, nr. 10-474; Rb. Arnhem 5 maart 2008, ECLI:NL:RBARN: 2008:BC6865, r.o. 2.4.

14. Art. 85 lid 1, 87 lid 6 en 799 lid 2 Rv; zie over deze plicht uitgebreid G. de Groot, 'Rechtsregels met betrekking tot de mondelinge behandeling', in: G. de Groot \& H. Steenberghe (red.), De mondelinge behandeling in civiele zaken, Den Haag: Boom juridisch 2019, par. 4.6.2.

15. Art. 88 lid $2 \mathrm{Rv}$; de rechter kan de gevolgtrekking maken die hij geraden acht wanneer een partij niet meewerkt, hetgeen impliceert dat procespartijen in beginsel worden geacht wel mee te werken.

16. Art. 111 lid 2 sub d, 278 lid 1, 282 lid 1 en 349 Rv. Deze eis ziet zowel op de juridische als op de feitelijke gronden, zie bijv. Rb. 's-Gravenhage 18 februari 2004, ECLI:NL:RBSGR:2004:AO9255, r.o. 3.3.
17. Art. 111 lid 3 Rv. De bedoeling van de wetgever was om deze bepaling ook voor de verzoekschriftprocedure in te voeren (art. 30a lid 3 sub f Rv$\mathrm{KEI)}$; door de vertraging in de digitalisering is ook de invoering van deze procesrechtelijke vernieuwing vertraagd. Voor beslagrekesten geldt de plicht al, zie de Beslagsyllabus en o.m. Hof Amsterdam 21 mei 2019, ECLI:NL:GHAMS:2019:1815, r.o. 3.3; Rb. Rotterdam (vzr.) 1 maart 2019, ECLI:NL:RBROT:2019:1699, r.o. 4.6 en 4.7.

18. Art. 128 lid 5 Rv.

19. Art. $162 \mathrm{Rv}$.

20. Art. 164, 165, 179 en $191 \mathrm{Rv}$.

21. Art. 196 en 198 lid 3 Rv.

22. Kamerstukken II 1999/2000, 26855, nr. 6, p. 12; A-G Wissink 14 september 2012, ECLI:NL:PHR:2012:BX7849 (X/St. Gerlach), onder 3.7.

23. Art. 201 lid $3 \mathrm{Rv}$. Zie voor de sanctionering van deze bepaling uitgebreid Hof 's-Hertogenbosch 14 december 2004, ECLI:NL:GHSHE: 2004:AS6385, JBPr 2005/26, m.nt. J.G.A. Linssen onder JBPr 2003/10, r.o. 4.2.1-4.2.8

24. Art. 382 sub a en b Rv.

25. Art. 382 sub c Rv.

26. HR 9 maart 2012, ECLI:NL:HR:2012:BU9204, NJ 2012/174; Hof Arnhem-Leeuwarden 21 augustus 2018, ECLI:NL:GHARL: 2018:7647, r.o. 2.16; Hof 's-Hertogenbosch 5 februari 2019, ECLI:NL:GHSHE:2019:396, r.o. 12.3.3; Rb. Limburg (ktr. Maastricht) 4 juli 2018, ECLI:NL:RBLIM:2018:6279, r.o. 3.2; Rb. Den Haag (vzr.) 29 juli 2019, ECLI:NL:RBDHA:2019:8237; Rb. Limburg 7 augustus 2019, ECLI:NL:RBLIM:2019:7281, r.o. 13.2.2.

27. De Bock 2011, par. 2.4.1; Rb. Den Haag (vzr.) 29 juli 2019 ECLI:NL:RBDHA:2019:8237; Hof 's-Hertogenbosch 5 februari 2019, ECLI:NL:GHSHE:2019:396, r.o. 12.3.3; Hof Amsterdam (OK) 27 mei 2019, ECLI:NL:GHAMS:2019:1754, r.o. 3.20. Minder stellig: Asser Procesrecht/Giesen 1 2015/78. 
of behoort te weten dat zij waar zijn, is in strijd met de waarheidsplicht. ${ }^{28,29}$

\subsection{De waarheidsplicht is (een aspect van) een rechtsbeginsel}

Art. $21 \mathrm{Rv}$ staat in een afdeling van het wetboek met de titel 'Algemene beginselen voor procedures' $(1.1 .3 \mathrm{Rv})$ en is in de toelichting op de Tijdelijke Experimentenwet rechtspleging benoemd als een van de fundamentele beginselen van procesrecht. ${ }^{30}$ In de toelichting bij art. $21 \mathrm{Rv}$ wijst de wetgever erop dat de waarheidsplicht nauw samenhangt met de in art. $22 \mathrm{Rv}$ neergelegde bevoegdheid van de rechter: art. $21 \mathrm{Rv}$ maakt civiele procespartijen medeverantwoordelijk voor de juistheid en volledigheid van de feiten op basis waarvan de rechter recht moet doen. ${ }^{31}$ Die verantwoordelijkheid hebben partijen niet alleen jegens elkaar, ${ }^{32}$ maar ook jegens de maatschappij. Die maatschappij heeft immers ook belang bij (de uitkomsten van) de civiele rechtspraak, ${ }^{33}$ en heeft er daarom belang bij 'dat de rechter zoveel mogelijk beslist op grond van de materiële waarheid. ${ }^{34}$ Art. 21 en 22 Rv regelen dus niet alleen een plicht voor partijen en een bevoegdheid voor de rechter, maar codificeren samen aspecten van een aloude ${ }^{35}$ kernwaarde van ons procesrecht: dat rechterlijke uitspraken zo veel mogelijk gebaseerd horen te zijn op de materiële waarheid. Hoewel niemand nog betwist dat rechterlijke uitspraken zo veel mogelijk gebaseerd horen te zijn op de materiële waarheid, bestaat er in de literatuur wel discussie over de vraag of dit uitgangspunt ook een rechtsbeginsel is. ${ }^{36} \mathrm{Ik}$ voeg me bij degenen die menen dat het dit inderdaad is; de toelichting op waarom ik dat vind, begin ik duidelijkheidshalve bij de benaming van het rechtsbeginsel.

28. De Bock 2011, par. 2.4.1; Hof Arnhem 27 juli 2004 , ECLI:NL:GHARN:2004:AR4652, r.o. 4.4; Hof 's-Hertogenbosch 7 juni 2016, ECLI:NL:GHSHE:2016:2302, r.o. 3.7.2; Hof's-Hertogenbosch 7 maart 2017, ECLI:NL:GHSHE:2017:890, r.o. 6.13-6.15; Hof Amsterdam (OK) 21 mei 2019, ECLI:NL:GHAMS:2019:1720, r.o. 3.4 .

29. Op de reikwijdte van de zorgplicht van partijen t.a.v. de feiten ga ik hier niet nader in; zie daarvoor: C.J-A. Seinen, 'De waarheidsplicht van art. $21 \mathrm{Rv}$ en de voor de beslissing relevante feiten', TvPP 2020, afl. 2, p. 29-34.

30. Kamerstukken II 2018/19, 35263, nr. 3, par. 4.4, p. 10 benoemt art. 19-22b en 25-30 Rv en art. 4, 5, 7, 12 en 13 Wet RO als 'grondrechten en fundamentele beginselen van procesrecht'.

31. Kamerstukken II 1999/2000, 26855, nr. 3, p. 53. Art. $21 \mathrm{Rv}$ was in het wetsvoorstel art. 1.3.3; art. $22 \mathrm{Rv}$ was art. 1.3.4.

32. Vgl. HR 18 mei 1979, ECLI:NL:HR:1979:AC6585, NJ 1980/213, m.nt. W.H. Heemskerk (Hulskorte/Van der Lek); zie ook de bespreking van de getuigplicht in de conclusie van A-G Franx voor dit arrest.

33. Kamerstukken II 1999/2000, 26855, nr. 5, p. 24-25. Vgl. Verslag van het wetgevingsoverleg d.d. 19 februari 2001, Kamerstukken II 2000/01, 26855, nr. 16, p. 17-19; minister Korthals d.d. 4 december 2001, Handelingen I 2001/02, nr. 10-507;

34. Kamerstukken II 1999/2000, 26855, nr. 5, p. 25. Zie ook o.m. Handelingen II 1910/11, p. 2201, eerste kolom; Kamerstukken II 1969/70, 10377, nr. 30, p. 10, eerste kolom; Kamerstukken II 1984/85, 10377, nr. 13, p. 13 en 19; Kamerstukken I 1986/87, 10377, nr. 61b, p. 9; Staatscommissie Gratama, Ontwerp tot vaststelling van een Wetboek van Burgerlijke Rechtsvordering (met toelichting), Den Haag: Algemeene Landsdrukkerij 1920, deel II, p. 5; G.C.C. Lewin, Het burgerlijk procesrecht is de pathologie van het recht (oratie Amsterdam UvA), Deventer: Kluwer 2013, par. 4; Asser Procesrecht/Van Schaick 2 2016/1.2.3.
Onder degenen die menen dat sprake is van een rechtsbeginsel, circuleren drie namen: ${ }^{37}$ het beginsel van de waarheidsplicht, ${ }^{38}$ het beginsel van de waarheidsvinding ${ }^{39}$ en het waarheidsbeginsel..$^{40}$ Elk van deze namen impliceert een andere invalshoek; zelf heb ik een voorkeur voor de term waarheidsbeginsel. Art. 19 lid 2, 22 en $24 \mathrm{Rv}$ en de ongeschreven regel van materiële rechtvaardigheid ${ }^{41}$ dragen de waarheidsvinding in het civiele proces op aan de rechter (en niet aan

35. Zie o.m. Rb. 's-Hertogenbosch 16 november 1962, NJ 1963/21 (Flint) Veldpaus); HR 22 december 1989, ECLI:NL:HR:1989:AD0997, NJ 1990/779, m.nt. J.B.M. Vranken (International Tin Council), r.o. 3.2 en 3.5; HR 13 september 1996, ECLI:NL:HR:1996:ZC2134, NJ 1996/731 (Van der Woude/Nedlloyd), r.o. 3.4; HR 4 oktober 1996, ECLI:NL:HR:1996:ZC2162; HR 11 september 1998, ECLI:NL:HR: 1998:ZC2701, NJ 1999/664, m.nt. M.M. Mendel (Overbeek Ziektekostenverzekering), r.o. 3.3; HR 30 oktober 2001, ECLI:NL:HR: 2001:ZD2513, NJ 2003/201 (aangifte door rechter), r.o. 4.3; HR 9 augustus 2002, ECLI:NL:HR:2002:AE6324, NJ 2004/47, m.nt. H.J. Snijders (notaris als partijgetuige), r.o. 4.1.3; HR 23 september 2003, ECLI:NL:HR:2003:AG3035, NJ 2004/9 (aangifte meineed), r.o. 3.3; J.P.A.N. Caroli, 'In hoever behooren de hoofdbeginselen, waarop de burgerlijke procedure in eersten aanleg berust, te worden gewijzigd?', in: Handelingen NJV, Deel I, 's-Gravenhage: Belinfante 1907, p. 1-125; de twee preadviezen van C.W. Star Busmann en J.G.L. Nolst-Trenité over de vraag, 'Moet aan procedeerende partijen de plicht zijn opgeleged om den rechter omtrent de feiten in te lichten? En zoo ja, in welken omvang?', in: Handelingen NJV, Deel I, 's-Gravenhage: Belinfante 1915, p. 152 c.q. p. 192; Minister Regout bij de installatie van de Staatscommissie Gratama 1920, deel I, p. IV; Staatscommissie Gratama 1920, deel II, p. 5 en 16-17; Grossmann 1935, p. 507-508 en 517; W.L. Haardt, 'De beginselen van het burgerlijk bewijs (Dienen bij overbrenging van het bewijsrecht naar het W.v.B.Rv. de fundamentele beginselen van dat bewijsrecht - zoals lijdelijkheid, vrije of gebonden bewijsleer - te worden herzien?)', in: Handelingen NJV, Deel I, Zwolle: W.E.J. Tjeenk Willink 1951, p. 62; C.W. Star Busmann/L.E.H. Rutten \& W.H. Ariëns, Hoofdstukken van burgerlijke rechtsvordering, Haarlem: Erven F. Bohn 1972, par. 208 en 248; M.J.A.M. Ahsmann, 'Van comparitie naar mondelinge behandeling. Over de rol van de advocaat en de pleitnota', NJB 2017/2376, par. 4.

36. Geen beginsel: Steenberghe, in: H. Steenberghe \& B. Gerretsen, 'Regie in de rechtspraak: de civiele rechter (2)', Rechtstreeks 2013, afl. 2, p. 43 (niet zozeer een beginsel, maar een gezamenlijke verantwoordelijkheid van alle procesdeelnemers); Asser Procesrecht/Giesen 1 2015/89 (geen basisvoorwaarde zonder welke het civiele proces niet eerlijk kan zijn).

37. Asser Procesrecht/Boonekamp 6 2020/20 noemt de waarheidsplicht niet afzonderlijk, maar duidt art. 19-30 Rv aan als 'fundamentele beginselen van behoorlijke rechtspraak en procesrecht'.

38. Minister Korthals tijdens het overleg d.d. 4 december 2001 m.b.t. het wetsvoorstel inzake de Aanpassing van de wetgeving aan de herziening van het procesrecht voor burgerlijke zaken, in het bijzonder de wijze van procederen in eerste aanleg (27824), Handelingen I 2001/02, nr. 10-507.

39. De Bock 2011, par. 2.6; M.A. Loth, Wat vinden wij als wij waarheid vinden? (Handelingen Nederlandse Juristen-Vereniging 142), Deventer: Kluwer 2012, p. 41, onder 6; Gerretsen, in: Steenberghe \& Gerretsen 2013, p. 39; reactie NOvA d.d. 17 januari 2014 op de Consultatie Wetsvoorstel wijziging van het Wetboek van Burgerlijke Rechtsvordering en de Algemene wet bestuursrecht in verband met vereenvoudiging en digitalisering van het procesrecht, par. 25; E.F. Groot, Het voorlopig getuigenverhoor (BPP nr. XVII) 2015/394; Asser Procesrecht/Asser $32017 / 29$ en 75; Hammerstein/Asser/De Bock/Ter Huurne/Van der Grinten, Adviesrapport Modernisering burgerlijk bewijsrecht, Bijlage bij de brief van de Minister d.d. 7 juni 2017, Kamerstukken II 2016-2017, 29279, nr. 384, par. 8 .

40. P.A.M. Meijknecht, Infrastructuur en hoofdbeginselen van burgerlijk procesrecht, Deventer: Kluwer 2013, par. 7.6.

41. Ahsmann 2017, p. 54. Vgl. Star Busmann 1915, p. 132, tweede volzin. 
partijen). Redenerend vanuit de in die bepalingen vervatte opdracht aan de rechter om binnen het door partijen geschapen kader zo veel mogelijk recht te doen overeenkomstig de materiële waarheid ${ }^{42}$ is er inderdaad reden om te spreken van het beginsel van waarheidsvinding. Echter: zoals de taak tot waarheidsvinding op de rechter rust, rust de plicht tot het aandragen van relevante ware feiten op procespartijen (en niet op de rechter). De opdrachten aan procespartijen en de rechter complementeren elkaar; zij staan bovendien in dienst van dezelfde fundamentele waarde als de plicht van getuigen om in rechte over de werkelijke situatie te komen verklaren ${ }^{43}$ en de plicht van deskundigen om een optimale bijdrage te leveren aan een zo waarheidsgetrouw mogelijke beslissing van het geschil. ${ }^{44}$ Alle procesdeelnemers zijn gehouden te bevorderen dat rechterlijke oordelen zoveel mogelijk op de materiële waarheid berusten. ${ }^{45}$ De term 'waarheidsbeginsel' dekt zowel de opdracht aan partijen als die aan de rechter, getuigen en deskundigen, en verduidelijkt de verhouding tussen de op die opdrachten ziende procesregels mijns inziens het beste. ${ }^{46}$

Alle aspecten van het zo begrepen waarheidsbeginsel - waaronder de waarheidsplicht - dienen de basale doelen van ons procesrecht. ${ }^{47} \mathrm{Zij}$ bevorderen dat in de procedure die materiële rechten worden verwezenlijkt die de rechtzoekende werkelijk toekomen - niet minder, maar ook niet méér. Het recht op een eerlijk proces als beschermd door art. 6 lid 1 EVRM brengt ook mee dat feiten die in geschil zijn en relevant zijn voor de beslissing, naar waarheid moeten worden vastgesteld. ${ }^{48}$ Een beslissing die wezenlijk afwijkt van de werkelijkheid zal door belanghebbenden niet als rechtvaardig worden ervaren, wat de vrijwillige naleving van die beslissing niet bevordert ${ }^{49}$ - en het voortbestaan van de rechtsorde dus evenmin. Daarom meen ik dat de uit hoofde van het waarheidsbeginsel op alle procesdeelnemers rustende plicht om eraan bij te dragen dat de rechterlijke uitspraak zoveel mogelijk gebaseerd is op de materiële waarheid, een basisvoorwaarde is zonder welke niet meer gezegd kan worden dat het

42. Kamerstukken I 2001/02, 26855, nr. 16, p. 22-23; Kamerstukken I 2001/02, 26855, nr. 16b, p. 4.

43. Art. 173 en 177 lid 2 Rv. Vgl. W.D.H. Asser, Grenzen aan de waarbeidsvorming in burgerlijke zaken. Heiligt het doel de bewijsmiddelen?, Deventer: Kluwer 1991, par. 1.4

44. G. de Groot, Het deskundigenadvies in de civiele procedure (diss. Amsterdam VU), Deventer: Kluwer 2008, p. 10; Asser Procesrecht/Asser 3 $2017 / 75$.

45. Vgl. HR 10 april 2009, ECLI:NL:HR:2009:BG9470, JBPR 2009/37, m.nt. J.F. Fleming, NJ 2010/471, m.nt. C.J.M. Klaassen, r.o. 3.3; Caroli 1907, p. 10-11 en 52 e.v.; Grossmann 1935; De Bock 2011, p. 53; G. de Groot, Waarheidsvinding in het civiele (proces)recht (Handelingen NJV 142), Deventer: Kluwer 2012, par. 3.6; Asser Procesrecht/Giesen 1 2015/79.

46. Vgl. P. Westerman, 'Naar een kritische en relevante rechtstheorie', NJLP 2019, afl. 2, p. 246: beginselen dienen als knooppunten voor meerdere regels en als normatieve rechtvaardiging voor die regels.

47. Vgl. Asser Procesrecht/Asser 3 2017/74. Zie over de doelen van het procesrecht Asser Procesrecht/Giesen 1 2015, par. 1.2.

48. Vgl.Kamerstukken II 1999/2000, 26855, nr. 5, p. 24; De Bock 2011, p. 66-68; De Groot 2012, p. 68.

49. L. Hulst, Experimental legal studies on perceived procedural justice and trust in law and society (diss. Amsterdam VU/Utrecht), Amsterdam: Off Page 2017. proces eerlijk is. Zonder het waarheidsbeginsel is ons stelsel van procesrecht niet langer geloofwaardig, eerlijk en werkbaar. $^{50}$

De aanname dat de waarheidsplicht een (aspect van een) rechtsbeginsel is, heeft betekenis voor de wijze waarop de rechter haar toepast. Rechtsbeginselen zijn namelijk niet slechts aspirationele waarden, maar in het recht verankerde normen aan de hand waarvan concretere rechtsregels worden opgesteld en toegepast, ${ }^{51}$ en de bron van waaruit leemten in het recht worden ingevuld. ${ }^{52}$ Rechtsbeginselen vormen de grens waaronder geen sprake is van recht(matig gedrag); ${ }^{53}$ regels die strijden met een rechtsbeginsel, zijn daarom ongeldig. ${ }^{54}$ Dit is slechts anders wanneer de conflicterende rechtsregel een uitingsvorm is van een ander rechtsbeginsel. Waar het waarheidsbeginsel botst met een ander rechtsbeginsel moet de rechter afwegen hoe het zich in dat specifieke geval tot het andere rechtsbeginsel verhoudt: tussen rechtsbeginselen bestaat geen vaste hiërarchie. ${ }^{55}$ Een indicatie voor het gewicht van het waarheidsbeginsel is wel dat het maatschappelijke belang dat de waarheid in rechte aan het licht komt in de jurisprudentie vaak zwaarder wordt geacht dan belangen die verlangen dat voor de beslissing relevante informatie buiten de

50. Vgl. Asser Procesrecht/Giesen 1 2015/8 en 89, die op basis van een vergelijkbare toets tot een (voorlopig) ander oordeel komt.

51. C. Smith, 'Het normatieve karakter van de rechtswetenschap: recht als oordeel', NJLP 2009, afl. 3, par. 1. Vgl. Asser 1991, par. 1.1; H.L.A. Hart, The concept of law, Oxford: Oxford University Press 1994, p. 127; A. Soeteman, 'Hercules aan het werk. Over de rol van rechtsbeginselen in het recht', $A A 1991 / 40$, p. 28; J.H. Nieuwenhuis, Waartoe is het recht op aarde?, Den Haag: Boom Juridische uitgevers 2006, o.m. p. 3 en 8.

52. Motie 23, aangenomen tijdens de beraadslagingen op 8 september 1953 'De wet dient aan te geven, hoe het recht moet worden gevonden bij het zwijgen der wet. De wet dient voor dit geval de volgende volgorde aan te wijzen: a. de aan de wet ten grondslag liggende rechtsbeginselen; b. het gebruik; c. de billijkheid', Handelingen II 1952/53, p. 2865-2879. Vgl. specifiek voor het burgerlijk procesrecht: J.A. van Dorp, M.P.J. Ruijpers \& E.M. Wesseling-van Gent, 'Wetsvoorstel 26 855: algemene voorschriften voor procedures', TCR 2000, afl. 2, p. 27.

53. In de termen van L.L. Fuller (The morality of law, Revised edition 1969 , New Haven: Yale University Press 2008, hoofdstuk 1) verschuiven rechtsbeginselen normen van 'morality of aspiration' naar 'morality of duty'. Vgl. G.H. Addink, 'De doorbraak van het beginselenrecht in het bestuursrecht. Enkele opmerkingen over een conceptueel beginselenrecht', in: T. de Gier (red.), Goed verdedigbaar, Deventer: Kluwer 2011, par. 6: rechtsbeginselen zijn geldend recht, de onderliggende waarden zijn dit door hun onbepaaldheid niet.

54. HR 12 april 1978, ECLI:NL:HR:1978:AX3264, ECLI:NL:HR: 1978:AC2432 en ECLI:NL:HR:1978:AM4447, BNB 1978/135-137 (Doorbraakarresten a.b.b.b.) en HR 16 mei 1986, ECLI:NL:HR: 1986:AC9354, NJ 1987/251, m.nt. M. Scheltema (Landbouwvliegers); HR 16 november 2001, ECLI:NL:HR:2001:AD5493, NJ 2002/469 (Varkenshouderij); HvJ EG (Grote Kamer) 22 november 2005, C-144/04, ECLI:EU:C:2005:709 (Mangold), par. 75 en 77; RvS 13 december 2017, ECLI:NL:RVS:2017:3408, r.o. 5. Vgl. art. 2.15 van de Aanwijzingen voor de regelgeving en de toelichting daarop (Stcrt. 2017, 69426). Door het toetsingsverbod geldt dit voor wetten in formele zin alleen als het beginsel (ook) in een verdrag is neergelegd.

55. Vgl. m.b.t. privacy en het belang van waarheidsvinding HR 11 september 1998, ECLI:NL:HR:1998:ZC2701, NJ 1999/664, m.nt. M.M. Mendel (Overlegging strafdossier), r.o. 3.3; m.b.t. het non-discriminatiebeginsel en de vrijheid van godsdienst HR 9 april 2010, ECLI:NL:HR: 2010:BK4549, NJ 2010/388, m.nt. E.A. Alkema (Staat en SGP/Clara Wichmann c.s.), r.o. 4.5.2-4.5.5. 
procedure wordt gehouden. ${ }^{56}$ Een belangrijke uitzondering vormt het fundamentele recht om een vertrouwenspersoon te kunnen raadplegen zonder vrees voor openbaarmaking van het besprokene. ${ }^{57}$

\subsection{Aard van het geschonden belang}

Sancties moeten als gezegd in overeenstemming zijn met de aard en de ernst van de schending. Om de aard en ernst van een schending te beoordelen, zal de rechter bezien welke waarden en welke belangen in welke mate zijn geschonden.

Daarbij is van belang dat de waarheidsplicht zowel de procedurele belangen van de wederpartij als de goede procesorde (zijnde een algemeen maatschappelijk belang) beschermt. ${ }^{58}$ Wanneer de feiten waarop de rechter zijn uitspraak baseert niet aansluiten bij de werkelijkheid waarmee partijen na die uitspraak weer verder moeten, leidt dat tot problemen - niet alleen voor de partij die onterecht ongelijk kreeg, maar mogelijk ook voor derden wier rechten met de door de uitspraak vastgestelde of gewijzigde rechtsverhouding samenhangen. Men kan de waarheidsplicht dan ook zien als de procesrechtelijke pendant van het materieelrechtelijke beginsel dat niemand over meer mag beschikken dan hem rechtens toekomt. ${ }^{59}$

Het algemeen belang bij de naleving van de waarheidsplicht betreft enerzijds het fundamentele belang dat de waarheid in rechte aan het licht komt ten dienste van een goede rechtsbedeling ${ }^{60}$ en anderzijds het meer aardse belang bij een rechtmatige en efficiënte inzet van publieke middelen als zittingsruimte en behandelingstijd door het rechterlijk appa-

56. Zie o.m. HR 22 december 1989, ECLI:NL:HR:1989:AD0997, r.o. 3.2 en 3.5; HR 2 mei 1997, ECLI:NL:HR:1997:AG7229, NJ 1998/237, m.nt. H.J. Snijders (Caransa/Lüske), r.o. 4.2; HR 20 december 2002, ECLI:NL:HR:2002:AE3350, NJ 2004/4, m.nt. J.B.M. Vranken (Lob), r.o. 4.4.4; HR 18 april 2014, ECLI:NL:HR:2014:942, NJ 2015/20, m.nt. M.M. Mendel en H.B. Krans (Arbeidsongeschiktheidsverzekering), r.o. 5.2.3; Rb. Almelo 14 februari 2005, ECLI:NL:RBALM: 2005:AS5919 (Wbp vs. art. 21 Rv), r.o. 8 en 9; Rb. Rotterdam 5 april 2006, ECLI:NL:RBROT:2006:AV9821, r.o. 1.4. Kritisch over de nadruk op rechterlijke waarheidsvinding: Asser Procesrecht/Van Schaick 22016/1.2.2

57. HR 3 april 2020, ECLI:NL:HR:2020:600 (Functioneel verschoningsrecht), r.o. 3.3.1 en 3.3.2.

58. Vgl. Hof Arnhem-Leeuwarden (zittingsplaats Leeuwarden) $14 \mathrm{mei}$ 2019, ECLI:NL:GHARL:2019:4138, r.o. 5.11 en 5.12; Rb. Amsterdam 16 mei 2012, ECLI:NL:RBAMS:2012:2429, r.o. 6.10 (laatste zin) en 6.17; GEA Curaçao 15 oktober 2018, ECLI:NL:OGEAC:2018:250, r.o. 2.11. Vgl. A-G Spier 27 november 2009, ECLI:NL:PHR: 2010:BK4995, onder 2.4.1 en 2.9.2; De Groot 2012, par. 3.6; 2019, p. 142; R.H. de Bock, 'Feitenonderzoek tijdens de mondelinge behandeling', in: G. de Groot \& H. Steenberghe (red.), De mondelinge behandeling in civiele zaken, Den Haag: Boom juridisch 2019, par. 5.2.3.

59. Vgl. De Groot 2008, p. 10; 2012, p. 83.

60. Zie de arresten in noot 56 en bijv. HR 1 maart 1985, ECLI:NL:HR: 1985:AC9066, NJ 1986/173, m.nt. W.L. Haardt onder NJ 1986/176 (Notaris Maas II); HR 7 juni 2002, ECLI:NL:HR:2002:AE0651, NJ 2002/394 (kantonrechter-getuige), r.o. 3.3; HR 19 september 2003, ECLI:NL:HR:2003:AF8273, NJ 2005/454, m.nt. W.D.H. Asser (Van Hulst/Van Eeuwijk), r.o. 3.3; HR 10 april 2009, ECLI:NL:HR: 2009:BG9470, r.o. 3.3. raat. ${ }^{61}$ Dat aardse belang - het besparen van tijd, geld en moeite - heeft de wederpartij uiteraard ook.

Bij de beoordeling in hoeverre een partij rekening moet houden met die belangen, spelen de hoedanigheid van partijen en de aard van de relatie tussen partijen een rol. Zoals zo vaak in het civiele recht is de kernvraag wat de wederpartij en de rechter als hoeder van de procesorde op grond van de wederzijdse hoedanigheden en relatie aan informatie en procesgedrag mochten verwachten.

\subsection{Waarbeidsplicht is een processuele plicht}

Een belangrijke beperking bij de sanctionering is dat de rechter procespartijen met art. 21 en $22 \mathrm{Rv}$ niet kan dwingen tot daadwerkelijke overlegging van stukken of andere informatie. ${ }^{62}$ De waarheidsplicht is een processuele plicht: de partij die ervoor kiest een vordering in te stellen of verweer te voeren, is gehouden om de informatie die nodig is voor de beoordeling daarvan in de procedure over te leggen. Of die partij dat ook daadwerkelijk doet, is een kwestie van partijautonomie. ${ }^{63}$ Doet zij het evenwel niet, dan heeft dat in de procedure negatieve gevolgen; het voldoen aan procedurele plichten dient in zoverre dus ook het eigenbelang van de procespartij.

Het gegeven dat de waarheidsplicht een processuele plicht is, brengt verder mee dat zij alleen ziet op gedragingen van partijen vanaf het moment dat een procedure tussen hen aanhangig is. ${ }^{64}$ Uiteraard zal de rechter processuele gedragingen steeds waarderen tegen de achtergrond van al hetgeen tussen partijen is voorgevallen, zodat buitenprocedurele gedragingen indirect ook relevant zijn voor de beoordeling van de proceshouding. Onwaarachtige buitenprocedurele gedragingen worden echter anders (want: materieelrechtelijk) beoordeeld dan onwaarachtige gedragingen in de procedure; men denke aan dwaling, bedrog, oneerlijke handelspraktijken, ongeldige ingebrekestelling, strijd met hetgeen in het maatschappelijk verkeer betaamt, et cetera. Wanneer dergelijke buitenprocedurele gedragingen in een procedure zowel materieelrechtelijk als

61. Vgl. EHRM 25 juni 1987, ECLI:NL:XX:1987:AC9931, NJ 1990/231, m.nt. E.A. Alkema (Capuano/Italië), par. 30; Kamerstukken I 2001/02, 26855, nr. 16, p. 10; zie uitgebreider met referentie an art. 6 EVRM ook p. 18-19; reactie minister op eindrapport 'Uitgebalanceerd', Kamerstukken II 2006/07, 30951, nr. 1, par. 26; Kamerlid Broekers-Knol bij de behandeling van de wetsvoorstellen inzake Rechterlijke organisatie/ Raad voor de rechtspraak/Procesrecht d.d. 4 december 2001, Handelingen I 2001/02, nr. 10-488.

62. Hof 's-Hertogenbosch 2 augustus 2011, ECLI:NL:GHSHE: 2011:BR4259, r.o. 3.11 en 3.12 .

63. Tenzij is voldaan aan de vereisten van art. $162 \mathrm{Rv}$, of als is voldaan aan de vereisten van art. $843 \mathrm{a}$ of $843 \mathrm{~b}$ Rv en de wederpartij een vordering op grond van een van die twee artikelen indient.

64. Vgl. Von Schmidt auf Altenstadt, in: GS Burgerlijke Rechtsvordering, art. $382 \mathrm{Rv}$, aant. 17.3. 
procesrechtelijk worden aangevallen, is niet steeds helder welk(e) toetsingskader(s) de rechter toepast. ${ }^{65}$

Overigens geldt ook andersom dat procesgedrag soms ook materieelrechtelijk kan worden gekwalificeerd: valsheid in geschrifte is niet alleen een schending van art. $21 \mathrm{Rv}$, maar ook een onrechtmatige daad en een misdrijf. In deze bijdrage ga ik hierop niet nader in; wel merk ik op dat de civiele rechter naar huidig recht niet ambtshalve gevolgen mag verbinden aan materieelrechtelijke kwalificaties van de verweten gedraging die geen onderdeel zijn van het partijdebat. ${ }^{66}$ Het aanvullen van rechtsgronden daarentegen is hem wel toegestaan.

Hoewel de gevolgtrekkingen die de rechter kan maken vergaand kunnen zijn, kan de rechter niet altijd voorkomen dat hij zijn oordeel uiteindelijk op onvolledige informatie moet baseren. ${ }^{67} \mathrm{Nu}$ het waarheidsbeginsel het best wordt gediend als het achterhouden van informatie wordt voorkomen, meen ik dat de dreiging van sancties - naast de normstelling - een belangrijk aspect is van art. $21 \mathrm{Rv} .{ }^{68}$ Rechters zetten de bepaling ook regelmatig preventief in, door er bij het opvragen van nadere informatie op te wijzen dat zij aan het uitblijven van een adequate reactie gevolgtrekkingen zullen verbinden. ${ }^{69}$ Voor het opleggen van een sanctie is die aankondiging niet nodig; rechters hopen dat de expliciete aanwezigheid van de stok het slaan overbodig maakt.

\section{Geraden gevolgtrekkingen in negen smaken}

Met die kanttekeningen kom ik toe aan een bespreking van de gevolgtrekkingen die rechters in de afgelopen periode geraden zijn voorgekomen. In de grote verscheidenheid van sancties ontwaar ik grofweg negen categorieën.

\subsection{Niet-beoordelen van de vordering}

De meest vergaande sanctie die Nederlandse rechters op schending van de waarheidsplicht stellen, is het in het geheel

65. Zie bijv. A-G Hartlief 15 november 2019, ECLI:NL:PHR:2019:1174 (Schending bijzondere zorgplicht/waarheidsplicht), onder 3.25 en 3.26; Rb. Almelo 17 oktober 2012, ECLI:NL:RBALM:2012:BY3008 (Dwaling/waarheidsplicht), r.o. 4.6 en 4.7; Rb. Zeeland-West-Brabant (vzr. Breda) 16 januari 2013, ECLI:NL:RBZWB:2013:BY8467 (Arbeidsrechtelijke spreekplicht/waarheidsplicht), r.o. 3.10 en 3.20; Rb. Rotterdam 20 maart 2013, ECLI:NL:RBROT:2013:BZ5645 (Onrechtmatige daad/ waarheidsplicht), r.o. 4.10-4.10.2; Rb. Noord-Nederland (zittingsplaats Leeuwarden) 15 januari 2014, ECLI:NL:RBNNE:2014:173 (Dwaling/ waarheidsplicht), r.o. 4.11 .

66. Met de invoering van art. 24 lid $2 \mathrm{Rv}$ (Wetsvoorstel modernisering bewijsrecht) zou de rechter wel suggesties mogen doen tot uitbreiding van de feitelijke grondslag. Dit staat mijns inziens op gespannen voet met de rechterlijke onpartijdigheid.

67. Zie bijv. HR 26 maart 2004, ECLI:NL:HR:2004:AO1330, NJ 2009/340 (Blokkering deskundigenrapport), r.o. 4.4 en de conclusie van A-G Wesseling-van Gent voor dit arrest, onder 4.45 .

68. Vgl. Asser Procesrecht/Giesen 1 2015/82; Asser Procesrecht/Asser 3 $2017 / 85$.

69. Zie bijv. GEA Aruba 25 november 2015, ECLI:NL:OGEAA:2015:530, r.o. 4.5; Rb. Limburg (ktr. Maastricht) 22 augustus 2018, ECLI:NL:RBLIM:2018:8603, r.o. 3.5 en 3.6; Hof's-Hertogenbosch 25 september 2018, ECLI:NL:GHSHE:2018:3970, r.o. 3.7.4; Hof Arnhem-Leeuwarden (zittingsplaats Leeuwarden) 14 mei 2019, ECLI:NL:GHARL:2019:4138, r.o. 5.15 en 5.16. Zie ook de modellen voor comparitievonnissen. niet beoordelen van de vordering van de betrokken procespartij. Deze sanctie kan twee vormen aannemen: niet-ontvankelijkheid of integrale toe- c.q. afwijzing van de vordering. ${ }^{70}$

\subsubsection{Niet-ontvankelijkheid}

Niet-ontvankelijkheid is wel een mogelijke, ${ }^{71}$ maar geen gebruikelijke sanctie op schending van de waarheidsplicht. Hoewel met enige regelmaat op schending van de waarheidsplicht gebaseerde niet-ontvankelijkheidsverweren worden gevoerd, worden die vaak verworpen. ${ }^{72}$ Een niet-ontvankelijkverklaring komt er immers op neer dat men de rechtzoekende (uiteindelijk) geheel of gedeeltelijk de toegang tot de rechter ontzegt; de drempel voor toepassing van die sanctie ligt door art. 47 Handvest EU en art. 6 EVRM hoog. Het recht op toegang tot de rechter is echter niet absoluut: formele tekortkomingen van de betrokken procespartij mogen meewegen bij de beoordeling of de procedure aan de eisen van art. 47 Handvest $\mathrm{EU}$ en art. 6 EVRM heeft voldaan. ${ }^{73}$

Voor wat betreft de substantiëringsplicht is de rechtspraak vrij eensgezind dat schending daarvan niet tot niet-ontvan-

70. Bij de sanctionering van de waarheidsplicht differentiëren noch de wettekst, noch rechters tussen verzoekschrift- en dagvaardingsprocedures. In deze bijdrage kunnen 'eiser' c.q. 'de vordering' daarom ook worden gelezen als 'verzoeker' c.q. 'het verzoek', tenzij expliciet anders is aangegeven.

71. HR 5 februari 2016, ECLI:NL:HR:2016:198, NJ 2016/94, r.o. 3.2.2-3.3; Hof Den Haag 9 april 2013, ECLI:NL:GHDHA: 2013:BZ6268, r.o. 6; Hof Arnhem-Leeuwarden 24 juni 2014, ECLI:NL:GHARL:2014:5094, r.o. 6.3, te kennen uit: ECLI:NL:PHR: 2015:2219, onder 2.1; Hof 's-Hertogenbosch 9 september 2014, ECLI:NL:GHSHE:2014:3557, r.o. 7.6.1; Hof Amsterdam 25 augustus 2015, ECLI:NL:GHAMS:2015:3480, r.o. 2.2; Rb. Rotterdam 21 januari 2020, ECLI:NL:RBROT:2020:483, r.o. 3.2; Hof Den Haag 28 januari 2020, ECLI:NL:GHDHA:2020:72, r.o. 10. Anders: Asser Procesrecht/Asser 3 2017/85; Hof Arnhem-Leeuwarden (zittingsplaats Leeuwarden) 14 januari 2020, ECLI:NL:GHARL:2020:329, r.o. 4.4 .

72. Zie o.m. Rb. Zeeland-West-Brabant (vzr. Breda) 16 januari 2013 , ECLI:NL:RBZWB:2013:BY8467, r.o. 3.10; Rb. Gelderland (zittingsplaats Arnhem) 15 januari 2014, ECLI:NL:RBGEL:2014:646, r.o. 4.4; Rb. Noord-Nederland (zittingsplaats Leeuwarden) 27 augustus 2014, ECLI:NL:RBNNE:2014:4210, r.o. 4.2; Rb. Midden-Nederland (vzr. Utrecht) 25 november 2016, ECLI:NL:RBMNE:2016:6290, r.o. 4.5; Rb. Limburg (ktr. Roermond) 9 september 2017, ECLI:NL:RBLIM: 2017:8742, r.o. 4.1 en 4.2; Rb. Limburg (ktr. Roermond) 11 juli 2018, ECLI:NL:RBLIM:2018:6581, r.o. 4.1.

73. Zie o.m. EHRM 28 februari 1977, 7450/76, D.R. 9, p. 110 (X/België $)$; EHRM 4 oktober 2001, 33776/96, ECLI:CE:ECHR: 2001:1004JUD003377696 (Potocka/Polen), par. 56 en 57. Vgl. A-G Wissink 14 september 2012, ECLI:NL:PHR:2012:BX7849 (X/St. Gerlach), onder 3.18. 
kelijkheid kan leiden. ${ }^{74}$ Dit ligt anders wanneer het niet vermelden van het verweer neerkomt op het weglaten van voor de beoordeling van de vordering essentiële informatie. Zo oordeelde de kantonrechter te Assen in een zaak waarin de eiser in de dagvaarding niet had vermeld dat de gedaagde gemotiveerd had gesteld dat de overeenkomst was ontbonden. ${ }^{75}$

Door het hem bekende verweer niet te vermelden had de eiser verwijtbaar de kans doen ontstaan dat zijn vordering bij verstek zou worden toegewezen. Het was voor eiseres immers voorzienbaar dat de rechter haar vordering niet zomaar zou toewijzen als de overeenkomst waarvan zij nakoming eiste mogelijk al was ontbonden. De motivering impliceert dat het desondanks indienen van de vordering zonder die informatie volgens de kantonrechter niet alleen een schending van de substantiëringsplicht was, maar een ernstige schending van de procesorde of zelfs misbruik van procesrecht. Op vergelijkbare gronden hebben andere rechters op vervalste stukken gebaseerde vorderingen niet-ontvankelijk verklaard. ${ }^{76}$

Een vergelijkbare motivering gaf ook de rechtbank Rotterdam ten aanzien van een vordering die namens een overledene aanhangig was gemaakt. De rechtbank verklaarde deze vordering niet-ontvankelijk - niet omdat in de dagvaarding geen (bestaande) eisende partij was vermeld (art. 111 lid 2 sub a Rv), maar wegens het in strijd met art. $21 \mathrm{Rv}$ en de beginselen van een goede procesorde vermelden van een eiser van wie degene die de dagvaarding deed uitgaan, wist dat die eiser was overleden. ${ }^{77}$

Hoewel niet-ontvankelijkheid als sanctie recht kan doen aan de ernst van een schending van een rechtsbeginsel, lijkt zij mij dogmatisch onzuiver. De waarheidsplicht is door haar verbondenheid met de materiële rechtsverhouding niet zonder inhoudelijke beoordeling te toetsen. Schending van procedurele normen waarvoor een inhoudelijke beoordeling van de

74. Zie o.m. Rb. Leeuwarden (ktr.) 18 augustus 2006, ECLI:NL:RBLEE: 2006:AY6468, r.o. 3.2.2-3.2.5; Rb. Rotterdam 16 september 2007, ECLI:NL:RBROT:2007:BA6194, r.o. 3.2; Rb. Almelo (vzr.) 17 september 2008, ECLI:NL:RBALM:2008:BF1955, r.o. 6; Rb. Utrecht 8 maart 2009, ECLI:NL:RBUTR:2009:BI0576, r.o. 4.2; Rb. Middelburg 29 september 2010, ECLI:NL:RBMID:2010:BO9485; Rb. Zutphen 16 maart 2011, ECLI:NL:RBZUT:2011:BQ1738, r.o. 7.1; Rb. Utrecht (ktr.) 19 oktober 2011, 721604 UC EXPL 10-18641 CTH 4065 (niet gepubliceerd), r.o. 4.3; Rb. Amsterdam (ktr.) 14 januari 2013, ECLI:NL:RBAMS:2013:BY8448, r.o. 9. Anders: Rb. 's-Hertogenbosch (ktr. Helmond) 11 november 2009, ECLI:NL:RBSHE: 2009:BK5649, r.o. 7 (wegens opzet partij en advocaat); Rb. Overijssel (ktr. Zwolle) 21 mei 2013, ECLI:NL:RBOVE:2013:CA0918, r.o. 2 en 7-9 (cumulatie schendingen art. 21 en 111 lid 2 en 3 Rv); Rb. Den Haag (ktr.) 3 mei 2018, ECLI:NL:RBDHA:2018:5530, r.o. 5.2.

75. Rb. Noord-Nederland (zittingsplaats Assen) 28 november 2018, ECLI:NL:RBNNE:2018:5114, r.o. 1.1.

76. Vgl. Rb. Roermond 7 mei 2008, ECLI:NL:RBROE:2008:7436 (niet gepubliceerd), welk vonnis is verbeterd bij Rb. Roermond 23 juli 2008, r.o. 3.5 en deels te kennen is uit Rb. Roermond 18 februari 2009 , ECLI:NL:RBROE:2009:BH3356, r.o. 3.1.

77. Rb. Rotterdam 8 december 2010, ECLI:NL:RBROT:2010:BP2476, r.o. 4.8. Vgl. m.b.t. bewust niet melden partijwijziging Hof Amsterdam 21 maart 2017, ECLI:NL:GHAMS:2017:985, r.o. 3.4; Rb. Limburg (zittingsplaats Maastricht) 8 oktober 2019 (ongepubliceerd), te kennen uit Hof 's-Hertogenbosch 2 januari 2020, ECLI:NL:GHSHE:2020:3, m.n. r.o. 3.6.6. zaak nodig is, leiden niet tot niet-ontvankelijkheid maar tot afwijzing van de vordering. ${ }^{78}$ Daarbij komt dat uitspraken tot niet-ontvankelijkheid ten aanzien van de onderliggende rechtsverhouding geen gezag van gewijsde hebben, zodat opnieuw over de kwestie kan worden geprocedeerd. Dit lijkt (juist) niet de bedoeling van de sanctie (vgl. par. 3.4.4).

\subsubsection{Direct integraal af- of toewijzen van de vordering}

In sommige zaken is met de constatering van een schending van de waarheidsplicht door de eiser ook direct duidelijk dat zijn vordering ongegrond is. ${ }^{79}$ Ook komt het voor dat de gedaagde de waarheidsplicht zo ernstig schendt, dat de rechter de vordering (reeds) op grond daarvan toewijst. ${ }^{80}$ Soms is de vergaande gevolgtrekking van directe toe- of afwijzing van de vordering terug te voeren op de aard van de rechtsverhouding. ${ }^{81}$ Vaker geldt dat de rechter uit de verweten gedraging opmaakt dat de betrokken partij hem moedwillig op het verkeerde been heeft willen zetten. ${ }^{82}$ Wanneer de rechter door de ernst van de schending niet meer vertrouwt op de waarheidsgetrouwheid van hetgeen een procespartij mondeling of schriftelijk naar voren brengt, is onvoldoende gesteld en wordt aan bewijslevering niet toegekomen. ${ }^{83}$ Ook komt het voor dat de rechter de vordering afwijst op grond van de goede procesorde, in die zin dat van de rechter en de wederpartij in redelijkheid niet kan worden gevergd dat zij de procedure voeren op basis van de onvolledige of onwaarachtige processtukken van de betrokken partij. ${ }^{84}$ Deze sancties komen erop neer dat de partij die het waarheidsbeginsel moedwillig schendt, verder gebruik van die instantie wordt ontzegd. Afwijzing of toewijzing houdt in dat de rechter de vordering ten gronde heeft beoordeeld; voor vorderingen onder de appelgrens is de kous daarmee af. 85

\section{- Repeat players}

Ten aanzien van repeat players die in consumentenzaken herhaaldelijk de op hen rustende waarheidsplicht schenden, signaleerde ik in 2014 dat met name in Limburg zaken van repeat players regelmatig een bijzondere, zaaksoverschrijdende beoor-

78. Vaste rechtspraak: HR 9 juli 2010, ECLI:NL:HR:2010:BM3979, NJ 2010/403 (EDDS/EDSC), r.o. 3.5; HR 13 maart 2020, ECLI:NL:HR: 2020:425 (Franken q.q./LaSer), r.o. 3.2.

79. Zie bijv. Rb. Zwolle-Lelystad (ktr. Zwolle) 29 maart 2005, ECLI:NL:RBZLY:2005:AT2634, r.o. 4.

80. Zie bijv. Rb. Limburg (vzr. Maastricht) 2 februari 2019, ECLI:NL:RBLIM:2019:1129, r.o. 4.7 (gemanipuleerde tekstberichten).

81. Rb. Limburg (zittingsplaats Maastricht) 13 juli 2018, ECLI:NL:RBLIM:2018:6731, r.o. 2.7.6 en 2.7.7 (onderhoudsplichten).

82. Hof Amsterdam (OK) 19 juli 2018, ECLI:NL:GHAMS:2018:2572, r.o. 3.9 en 3.17; Hof Amsterdam 20 oktober 2019, ECLI:NL:GHAMS: 2019:3879, r.o. 3.7; Rb. Limburg (ktr. Maastricht) 15 augustus 2018, ECLI:NL:RBLIM:2018:7797, r.o. 4.13; Rb. Noord-Holland 21 november 2018, ECLI:NL:RBNHO:2018:10184, r.o. 4.2.

83. Zie bijv. Hof Amsterdam 13 januari 2015, ECLI:NL:GHAMS: 2015:85, r.o. 3.12 .

84. Rb. Limburg (ktr. Maastricht) 14 mei 2014, ECLI:NL:RBLIM: 2014:4493; Rb. Noord-Holland (ktr. Alkmaar) 26 juli 2017, ECLI:NL:RBNHO:2017:6234, r.o. 5.7-5.11.

85. Weliswaar staat cassatieberoep open op grond van art. $80 \mathrm{Wet} \mathrm{RO}$, maar dit zal door de discretionaire aard van de bevoegdheid tot sanctionering doorgaans geen soelaas bieden. 
deling kregen, in die zin dat verstrekkender sancties werden opgelegd aan repeat players die in andere zaken al waren terechtgewezen. ${ }^{86}$ Inmiddels zijn kantonrechters landelijk gaan benadrukken dat de hoofdregels van art. 21 en 111 lid 2 en $3 \mathrm{Rv}$ ook voor repeat players gelden, op de gebruikelijke wijze en in elke individuele zaak.

In consumentenverstekzaken kregen repeat players van de teams kanton van de rechtbanken Amsterdam en Den Haag in de periode van 1 juli 2019 tot 1 oktober 2019 bij tussenvonnis de mogelijkheid om de voor de beslissing relevante informatie alsnog aan te leveren, door het invullen van een standaardformulier en overlegging van de daarin aangegeven stukken - onder toezending van een kopie aan de consument, die daarop mocht reageren. ${ }^{87}$ Sinds 1 oktober 2019 wordt door deze gerechten geen aanvullende informatie meer opgevraagd, maar worden onvoldoende onderbouwde vorderingen zonder nadere proceshandelingen afgewezen op grond van art. 21 en 111 lid 2 Rv. ${ }^{88}$ Wordt de vordering na de nadere toelichting alsnog toegewezen, dan blijven de kosten voor de extra proceshandeling - inclusief betekeningskosten indien sprake is van een wijziging van eis - voor rekening van de eiser. Andere gerechten gaven repeat players nog tot 1 april $2020 \mathrm{bij}$ tussenvonnis de gelegenheid om informatie bij te brengen ${ }^{89}$ soms zelfs tot tweemaal toe. ${ }^{90}$ Juridisch noodzakelijk was deze exercitie niet: de in deze pilot benadrukte informatieplichten vloeien al jaren voort uit de wet. Wel heeft de pilot de norm van 'volledige informatievoorziening uit eigen beweging' opnieuw onder de aandacht gebracht, en bevordert het de rechtseenheid dat rechters die norm voortaan landelijk eenduidig(er) toepassen.

\subsection{Benoemen schending}

Aan het andere uiterste van het spectrum treft men uitspraken waarin de enige 'sanctie' is dat de rechter de schending als

86. Bijv. Rb. Limburg (ktr. Maastricht) 9 april 2014, ECLI:NL:RBLIM: 2014:3492; Rb. Limburg (ktr. Maastricht) 7 mei 2014, ECLI:NL:RBLIM:2014:4746,

87. Zie bijv. Rb. Amsterdam (ktr.) 29 oktober 2019, ECLI:NL:RBAMS: 2019:7988; Rb. Amsterdam (ktr.) 31 oktober 2019, ECLI:NL:RBAMS: 2019:7994; Rb. Amsterdam (ktr.) 5 november 2019, ECLI:NL:RBAMS:2019:8239; Rb. Amsterdam (ktr.) 15 november 2019, ECLI:NL:RBAMS:2019:8516.

88. Zie bijv. Rb. Den Haag (ktr.) 2 juli 2019, ECLI:NL:RBDHA: 2019:7920 (die dag zijn meer ongepubliceerde zaken op dezelfde wijze afgedaan); Rb. Amsterdam (ktr.) 5 november 2019, ECLI:NL:RBAMS: 2019:8116; Rb. Amsterdam (ktr.) 13 december 2019, ECLI:NL:RBAMS:2019:9628; Rb. Amsterdam (ktr.) 3 februari 2020, ECLI:NL:RBAMS:2020:448.

89. Zie www.rechtspraak.nl/SiteCollectionDocuments/landelijkinformatieformulier-ambtshalve-toetsen-consumentenzaken.pdf.

90. Rb. Noord-Nederland (ktr. Assen) 10 maart 2020, ECLI:NL:RBNNE: 2020:1209, r.o. 2.4.

91. Rb. Rotterdam 14 december 2011, ECLI:NL:RBROT:2011:BV3822; Rb. Limburg (zittingsplaats Maastricht) 29 januari 2014, ECLI:NL:RBLIM:2014:742, r.o. 3.45 en 3.46; Rb. Den Haag (vzr.) 4 augustus 2014, ECLI:NL:RBDHA:2014:10520, r.o. 3.1; Rb. Limburg (zittingsplaats Maastricht) 1 april 2015, ECLI:NL:RBLIM:2015:2610, r.o. 2.9, 2.22-2.33 en 2:56; Hof Amsterdam (OK) 10 oktober 2019, ECLI:NL:GHAMS:2019:3639, r.o. 3.3 en 3.15 . zodanig benoemt, ${ }^{91}$ een schriftelijke 'tik op de vingers' ${ }^{92}$ ter inscherping van de op de procespartij rustende plichten. ${ }^{93}$

Soms geven de gekozen bewoordingen de indruk dat de rechter ten onrechte ${ }^{94}$ meende dat alleen schendingen ten aanzien waarvan opzet is gesteld en gebleken gesanctioneerd kunnen worden. ${ }^{95}$ In andere gevallen benoemt of impliceert de rechter dat geen van partijen optimaal heeft geprocedeerd, zodat hij maar aan het werk is gegaan - ofwel met het dossier zoals dat er lag, dan wel door het opvragen van nadere informatie. ${ }^{96}$ Verder komt het voor dat de rechter een vordering of verweer op zelfstandig dragende materiële gronden afwijst of passeert, maar ten overvloede ook de schending van de waarheidsplicht benoemt.

Van een heel ander gewicht is het wanneer de Ondernemingskamer een schending van de waarheidsplicht benoemt, onder toevoeging van de zinsneden:

'Dit alles klemt temeer nu de juiste uitvoering van het "Finanzkonstrukt" tot de verantwoordelijkheid van $[\mathrm{A}]$ behoorde. $\mathrm{Nu}$ geen van partijen hierom heeft verzocht, zal de Ondernemingskamer zich echter niet ook in het dictum over de verantwoordelijkheid voor het wanbeleid uitspreken.' ${ }^{\text {'9 }}$

Met die toelichting zal de benoeming van de schending in vervolgprocedures tegen de betrokkene een voor hem negatieve invloed kunnen hebben: hoewel de aansprakelijkheidsrechter zijn eigen oordeel moet vormen, staat degene op wie de geciteerde overweging ziet in een aansprakelijkheidsprocedure toch met 1-0 achter. Ditzelfde geldt voor de kwalificatie door een hof van een schending van de waarheidsplicht als 'grof en 'misbruik van procesrecht', ${ }^{98}$ en de overweging ten overvloede in een kort geding dat het hof geen bevel op grond van art. 21

92. Getuige zinsneden als 'De eisende partij alsmede de namens haar optredende deurwaarder dienen zich dit aan te trekken' (Rb. Den Haag (ktr.) 2 juli 2019, ECLI:NL:RBDHA:2019:7920). Afkeurend zonder verdere gevolgtrekking bijv. ook: Rb. Groningen (vzr.) 23 januari 2003, ECLI:NL:RBGRO:2003:AF3622, r.o. 4.3; Hof Amsterdam 21 mei 2019, ECLI:NL:GHAMS:2019:1720, r.o. 3.4.

93. Hof Amsterdam (OK) 21 mei 2019, ECLI:NL:GHAMS:2019:1720, r.o. 3.4; Rb. Amsterdam (ktr.) 28 oktober 2019, ECLI:NL:RBAMS: 2019:7986.

94. Zie bijv. HR 15 september 2017, ECLI:NL:HR:2017:2360, r.o. 5.3.4; Hof 's-Hertogenbosch 10 december 2019, ECLI:NL:GHSHE: 2019:4470, r.o. 3.9.3; Rb. Maastricht (vzr.) 26 juni 2003, ECLI:NL:RBMAA:2003:AI6157, r.o. 3.6; Rb. Rotterdam 10 juni 2009, ECLI:NL:RBROT:2009:BI9853, r.o. 5.8.

95. Rb. Almelo 21 december 2011, ECLI:NL:RBALM:2011:BV0428, r.o. 7.3-7.6; Rb. Limburg (zittingsplaats Maastricht) 1 april 2015, ECLI:NL:RBLIM:2015:2610, r.o. 2.28; Rb. Rotterdam 24 januari 2018, ECLI:NL:RBROT:2018:1038, r.o. 5.2 en 5.3.

96. Zie bijv. GEA Aruba 25 november 2015, ECLI:NL:OGEAA:2015:530, r.o. 4.2 en 4.3; Rb. Rotterdam (vzr.) 14 november 2016, ECLI:NL:RBROT:2016:10103, r.o. 4.3 en 4.4; Rb. Den Haag (vzr.) 8 mei 2019, ECLI:NL:RBDHA:2019:4561, r.o. 3.16 en 3.18 .

97. Hof Amsterdam (OK) 16 december 2019, ECLI:NL:GHAMS 2019:4691, r.o. 4.10.

98. Hof Den Haag 8 oktober 2019, ECLI:NL:GHDHA:2019:3289, r.o. 38 en 39 . 
en $22 \mathrm{Rv}$ zou geven omdat het desbetreffende onderwerp in die procedure niet voorlag, 'hoewel de daarop ziende grief wel terecht' was. ${ }^{99}$ Mogelijk wilden de rechters met de overwegingen ten overvloede de geschonden norm inscherpen; het effect ervan kan echter neerkomen op een zware sanctie, die gegrond is op een materieelrechtelijke kwalificatie die (kennelijk) niet aan hen voorlag.

\subsection{Waardering/uitleg stellingen en stukken}

De meest gemaakte gevolgtrekking uit schendingen van de waarheidsplicht is het in meer of mindere mate diskwalificeren van stellingen en/of stukken van de betrokken procespartij. Dat kan beperkt blijven tot het extra kritisch bezien van stellingen over het onderwerp ten aanzien waarvan de schending is gebleken - wat overigens nog steeds tot integrale toec.q. afwijzing van de vordering kan leiden, ${ }^{100}$ het extra kritisch bezien van alle stellingen van de betrokken partij, ${ }^{101}$ of het vestigen van een vermoeden waartegen de betrokken partij tegenbewijs mag leveren. ${ }^{102} \mathrm{Bij}$ ernstiger schendingen kan de rechter de stellingen van de betrokken partij integraal passeren (zie par. 4.1), uitgaan van de juistheid van de stellingen van de wederpartij zonder mogelijkheid van tegenbewijs, ${ }^{103}$ of als vaststaand aannemen dat de ontbrekende informatie voor de betrokken partij nadelig is. ${ }^{104} \mathrm{Al}$ deze sancties betreffen de waardering en/of uitleg van stellingen en bewijsmiddelen; de stelplicht en bewijslast blijven rusten waar zij volgens de hoofdregels van art. 149 en $150 \mathrm{Rv}$ horen.

Beginnend bij de processuele positie van de eiser: die dient zijn vordering te onderbouwen met stellingen die tot toewijzing daarvan kunnen leiden. Wanneer een voor toewijzing van de vordering essentiële stelling wegvalt omdat de rechter wegens schending van de waarheidsplicht aan die stelling voorbijgaat, heeft de eiser netto bezien onvoldoende gesteld om tot toewijzing van zijn vordering te komen (art. 111 lid 2 aanhef en sub d Rv). Aan de vraag of de wederpartij de vordering voldoende heeft betwist en bewijslevering komt de rechter dan

99. Hof Arnhem-Leeuwarden (zittingsplaats Arnhem) 5 november 2019, ECLI:NL:GHARL:2019:9502, r.o. 5.7.

100. Zie bijv. Rb. Amsterdam 16 mei 2012, ECLI:NL:RBAMS:2012:2429, r.o. 6.11; Rb. Amsterdam 10 april 2013, ECLI:NL:RBAMS: 2013:BZ7002, r.o. 4.6 en 4.14.

101. Zie bijv. Rb. Amsterdam (ktr.) 8 januari 2016, ECLI:NL:RBAMS: 2016:186, r.o. 8 .

102. Zie bijv. Rb. Den Haag 23 januari 2019, ECLI:NL:RBDHA:2019:679, r.o. 4.16-4.19; Rb. Limburg (zittingsplaats Maastricht) 20 maart 2019, ECLI:NL:RBLIM:2019:2584, r.o. 10.4.1.

103. Zie o.m. Hof Leeuwarden 24 januari 2007, ECLI:NL:GHLEE: 2007:AZ7479; Hof Den Haag 26 maart 2019, ECLI:NL:GHDHA: 2019:749, r.o. 10 (slot); Hof Arnhem-Leeuwarden (zittingsplaats Arnhem) 29 maart 2019, ECLI:NL:GHARL:2019:3287, r.o. 5.10 en 5.11 Uit de wetsgeschiedenis blijkt dat de wetgever deze sanctie voor ogen stond voor gevallen waarin een partij het voorschot voor een deskundigenbericht niet tijdig voldoet, zie Kamerstukken II 1999/2000, 26855, nr. 5 , p. 66

104. HR 14 november 2014, ECLI:NL:HR:2014:3241, NJ 2015/193, m.nt. D.W.F. Verkade (X./Jumbo), r.o. 4.2.4. Zie recent bijv. Rb. Limburg (zittingsplaats Maastricht) 3 april 2019, ECLI:NL:RBLIM:2019:3076, r.o. 4.2 ten aanzien van die vordering niet meer toe. ${ }^{105}$ In deze variant kan het ook gaan om de situatie waarin een dragende stelling in strijd met de waarheid blijkt, waardoor de vordering grondslag ontbeert, of om een situatie waarin de rechter zich zodanig voorgelogen acht dat hij geen van de stellingen van de betrokken partij nog geloofwaardig acht ${ }^{106}$ - inclusief eventuele alternatieven voor de stelling waarvan de onjuistheid is gebleken. ${ }^{107}$

Dan is er nog de situatie waarin de rechter deels aan de stellingen van de eiser voorbijgaat en de resterende stellingen - indien zij komen vast te staan - de vordering nog zouden kunnen dragen. In dat geval moet de rechter beoordelen of de wederpartij de vordering voldoende heeft betwist; die beoordeling vindt plaats in het licht van de overgebleven stellingen van de eiser én van het feit dat die eiser de op hem rustende waarheidsplicht heeft geschonden. De uitkomst van deze afweging is vaak dat de wederpartij de vordering voldoende heeft betwist. De hoofdregel van art. $150 \mathrm{Rv}$ brengt dan mee dat de eiser zijn stellingen moet bewijzen. Wanneer de eiser eerder creatief of onwillig is omgegaan met het bewijs, kan dit bij de waardering van bijgebracht bewijs meewegen. ${ }^{108}$

Bezien vanuit de processuele positie van de gedaagde geldt dat die zijn verweer voldoende moet onderbouwen. Wanneer een voor dat verweer essentiële stelling wegvalt omdat de rechter die passeert wegens schending van de waarheidsplicht, heeft de gedaagde onvoldoende gesteld om tot honorering van zijn verweer te komen en/of tot bewijslevering te worden toegelaten. Feiten of rechten die door de eiser voldoende zijn gesteld en door de wederpartij niet voldoende zijn betwist, moet de rechter op grond van art. 149 lid $1 \mathrm{Rv}$ als vaststaand beschouwen. Aan bewijslevering komt men dan niet toe.

\subsection{Afwijking van een processuele hoofdregel}

Een uitspraak die een partij iets geeft dat haar niet werkelijk toekomt, is niet rechtvaardig, ${ }^{109}$ voor partijen slecht

105. Zie bijv. Rb. Rotterdam 16 oktober 2019, ECLI:NL:RBROT: 2019:8418, r.o. 4.9; Rb. Amsterdam (ktr.) 28 oktober 2019, ECLI:NL:RBAMS:2019:7986; Rb. Noord-Nederland (zittingsplaats Assen) 18 december 2019, ECLI:NL:RBNNE:2019:5219, r.o. 2.4 .

106. Zie bijv. A-G Spier in zijn conclusie voor HR 12 september 2008, ECLI:NL:HR:2008:BD6028 (art. 81 RO), onder 3.3.1 en 3.3.2; Rb. Midden-Nederland (zittingsplaats Utrecht) 11 april 2017, ECLI:NL:RBMNE:2017:1879.

107. Zie bijv. Rb. 's-Gravenhage (ktr. Leiden) 14 januari 2004, ECLI:NL:RBSGR:2004:AP0103.

108. Zie bijv. Rb. Den Haag 18 september 2019, ECLI:NL:RBDHA: 2019:10564, r.o. 2.2.

109. Vgl. A-G Asser in zijn conclusie voor HR 4 oktober 1996, ECLI:NL:HR:1996:ZC2162, onder 2.4, en Snijders in zijn noot bij de drie herroepingsarresten uit 1996 in NJ 1998/46, par. 8; Loth 2012, p. 18-19 en zijn 'Overkoepelend vraagpunt' dat tijdens de beraadslagingen van de Nederlandse Juristen-Vereniging over 'Waarheid en waarheidsvinding in het recht' door de leden in 'zeer ruime meerderheid bevestigend' werd beantwoord (p. 15); De Groot 2012, p. 54. 
voorspelbaar ${ }^{110}$ en voor ten minste één van partijen onaanvaardbaar. Aan het vertrouwen in de rechtspraak draagt een op fictie gebaseerd rechterlijk oordeel in elk geval niet bij. ${ }^{111}$ Hoe belangrijk de waarheidsgetrouwheid van rechterlijke beslissingen wordt gevonden, blijkt onder meer uit het feit dat schendingen van de waarheidsplicht regelmatig grond geven voor uitzonderingen op processuele hoofdregels, zoals die voor stelplicht en bewijslast (par. 3.4.1); de 'tweeconclusieregel' en de 'in beginsel strakke regel' voor eiswijzigingen in appel (par. 3.4.2), de leer van de bindende eindbeslissing (par. 3.4.3) en de herkansingsfunctie van het appel (par. 4.4).

\subsubsection{Afwijking van art. 149/150 Rv}

Zowel art. 149 lid 1 als art. $150 \mathrm{Rv}$ biedt ruimte voor afwijking van de hoofdregel:

\section{'Artikel 149 lid 1 Rv}

Tenzij uit de wet anders voortvloeit, mag de rechter slechts die feiten of rechten aan zijn beslissing ten grondslag leggen, die in het geding aan hem ter kennis zijn gekomen of zijn gesteld en die overeenkomstig de voorschriften van deze afdeling zijn komen vast te staan. (...)'

\section{'Artikel 150 Rv \\ De partij die zich beroept op rechtsgevolgen van door haar gestelde feiten of rechten, draagt de bewijslast van die fei- ten of rechten, tenzij uit enige bijzondere regel of uit de eisen van redelijkheid en billijkheid een andere verdeling van de bewijslast voortvloeit.'}

De waarheidsplicht is een wettelijke plicht, op schending waarvan de rechter volgens de wet de sanctie mag stellen die hem geraden voorkomt. Hoewel rechters de geraden gevolgtrekking vaker zoeken in de sfeer van de waardering van de stellingen en stukken van de partij die de waarheidsplicht schendt, zijn er ook zaken waarin zij overgaan tot een afwijking op de hoofdregels van stelplicht en bewijslast.

Zo komt het voor dat hoewel de rechter wegens schending van de waarheidsplicht voorbijgaat aan een deel van de stellingen waarop de eis en/of het verweer berusten, de stellingen die aan beide kanten overblijven alsnog aan de stelplicht en de betwistingslast voldoen. Dit doet zich vooral voor in zaken waarin de vordering of het verweer op open normen berust, zoals onrechtmatigheid, verwijtbaarheid en causaliteit. In dergelijke gevallen zou de eiser volgens de hoofdregel van art. $150 \mathrm{Rv}$ de betwiste gronden voor zijn vordering moeten bewijzen c.q. de

110. Vgl. De Bock (2011, par. 4.2), die overigens met Luhmann lijkt te menen dat de onvoorspelbaarheid van het waarheidsgehalte de procedure haar legitimerende werking geeft: partijen verrichten alle vereiste proceshandelingen, juist omdat zij niet weten of zij de procedure zullen winnen of verliezen.

111. Vgl. F. Bruinsma, De Hoge Raad van onderen, Deventer: Kluwer 2010; Loth 2012, par. 5; advies van de NOvA d.d. 17 januari 2014, Kamerstukken II 2013/14, 34059, nr. 3, blg-396185, par. 25. gedaagde de betwiste gronden voor een bevrijdend verweer. ${ }^{112}$ De onwaarachtige of onzorgvuldige proceshouding van de wederpartij kan dan tot het oordeel leiden dat het bewijsrisico voor het tegendeel op grond van de redelijkheid en billijkheid geheel bij die wederpartij komt te liggen. ${ }^{113}$ Ook kan de rechter oordelen dat de partij waarop de bewijslast rust voorshands aan die bewijslast heeft voldaan en de andere partij toelaten tot tegenbewijs. ${ }^{114}$ De rechter legt dan wel een dubbele sanctie op: enerzijds passeert hij stellingen en daarnaast verschuift of verzwaart hij feitelijk de stel- of betwistingsplicht. ${ }^{115}$ Soms zal hij hiervoor (ook nog) moeten terugkomen van een bindende eindbeslissing ${ }^{116}$ (zie par. 3.4.3). Gezien de vrijheid die ons bewijsrecht de rechter laat bij de waardering van stellingen en bewijs, en gezien de hiervoor onderstreepte frasen in art. 149 en $150 \mathrm{Rv}$, is de rechter bevoegd om dit alles te doen. ${ }^{117}$ Wel meen ik dat hij moet benoemen welke omstandigheden deze (meervoudige) gevolgtrekking rechtvaardigen, om de proportionaliteit van de sanctie toetsbaar te houden. ${ }^{118}$

\subsubsection{Verplichten tot of toestaan van extra proceshandeling}

In beginsel bestaat de procedure zowel in eerste aanleg als in appel uit een schriftelijke ronde en een mondelinge behandeling, waarna de behandeling wordt gesloten en uitspraak volgt. Wanneer er lopende het geding echter aanleiding ontstaat voor het vermoeden dat de waarheidsplicht is geschonden, kan de rechter de partij jegens welke dat vermoeden is gerezen in de gelegenheid stellen een nadere toelichting te geven of bevelen bepaalde informatie alsnog in het geding te brengen. ${ }^{119}$ Met dat verzoek of bevel onderstreept de rechter dat de gevraagde informatie naar zijn oordeel relevant is voor de gevraagde beslissing; voorzover er voordien al onduidelijkheid over had kunnen bestaan of de informatie relevant was, dan kan dit nadien alleen als de partij zich expliciet en met succes beroept op de uitzondering van art. 22 lid 2 Rv. Voldoet de partij zonder goede reden niet aan het verzoek of bevel, dan volgt doorgaans een expliciete sanctie - al dan niet in de vorm dat de vordering of het verweer wordt afgedaan op

112. Zie bijv. Rb. Midden-Nederland (zittingsplaats Utrecht) 16 oktober 2019, ECLI:NL:RBMNE:2019:4813, r.o. 3.25-3.27.

113. Oftewel omkering van de bewijslast, zie Asser Procesrecht/Asser 3 $2017 / 292$.

114. Oftewel gedeeltelijke verschuiving van het bewijsrisico, zie Asser Procesrecht/Asser 32017/292.

115. Zie bijv. Rb. Den Haag 23 januari 2019, ECLI:NL:RBDHA:2019:679, r.o. 4.15-4.19. Vgl. Hof 's-Hertogenbosch 14 december 2004, ECLI:NL:GHSHE:2004:AS6385, r.o. 4.2.5-4.2.8.

116. Rb. Zwolle (ktr. Deventer) 20 februari 2003, ECLI:NL:RBZWO 2003:AN4512, r.o. 3 en 4

117. B.T.M. van der Wiel, De rechtsverhouding tussen procespartijen (diss. Leiden), Deventer: Kluwer 2004, p. 334 en H.M. ten Haaft, 'Eerste aanleg', TCR 2007, afl. 1, p. 15, tweede kolom) menen dat omkering van de bewijslast alleen mogelijk is in gevallen waarin de wederpartij niet aan haar betwistingslast heeft voldaan.

118. Volgens de vaste maatstaf van HR 4 juni 1993, ECLI:NL:HR 1993:ZC0986, NJ 1993/659, m.nt. D.W.F. Verkade (Vredo/Veenhuis), r.o. 3.4. Zie over de wenselijkheid van motivering bij de toepassing van vage normen B.T.M. van der Wiel, 'Motivering door de Nederlandse cassatierechter', TCR 2018, afl. 3, par. 8

119. Op grond van art. 21, 22 en eventueel 87 lid 2 en 7 Rv. 
een gebrek aan onderbouwing. ${ }^{120}$ Overigens kan de extra proceshandeling op zich al een sanctie zijn, in die zin dat ook als de vordering op grond van de alsnog ingebrachte informatie wordt toegewezen of het daarop gegronde verweer slaagt, de extra proceshandeling buiten de berekening van de forfaitaire proceskostenveroordeling kan worden gehouden. ${ }^{121}$

Een schending van de waarheidsplicht door de ene partij kan ook juist grond zijn om de wederpartij een extra proceshandeling toe te staan. Die proceshandeling kan strekken tot een vermeerdering of wijziging van de vordering of het verweer in stadia van de procedure waarin dit normaal gesproken niet meer zou kunnen: de schending van de waarheidsplicht sec en de alsnog gebleken (juiste) feiten zijn nieuwe omstandigheden die de laattijdige aanpassing rechtvaardigen. ${ }^{122}$ Wanneer het (meer) op de weg van een partij had gelegen om een bepaald stuk zelf in het geding te brengen, zal zij zich er niet snel tegen kunnen verzetten dat haar wederpartij het stuk nadien in het geding brengt, ook niet als die wederpartij dat wellicht eerder had kunnen doen. ${ }^{123}$

\subsubsection{Afwijking leer van bindende eindbeslissing/ terugkomen op eerder oordeel}

Wanneer een schending van de waarheidsplicht pas wordt geconstateerd nadat de rechter op grond van de gediskwalificeerde stellingen al eindbeslissingen had genomen, kan dit voor de rechter grond opleveren om - al dan niet ambtshal$\mathrm{ve}^{124}$ - terug te komen van een of meer bindende eindbeslissingen. Volgens vaste rechtspraak kan dit omdat de eisen van een goede procesorde meebrengen dat de rechter aan wie is gebleken dat een eerder door hem gegeven, maar niet in een einduitspraak vervatte, eindbeslissing berust op een onjuiste juridische of feitelijke grondslag, bevoegd is om, nadat partijen de gelegenheid hebben gekregen zich dienaangaande uit te laten, over te gaan tot heroverweging van die eindbeslissing dit om te voorkomen dat hij op een ondeugdelijke grondslag een einduitspraak zou doen. ${ }^{125}$ Hoewel schaars, komt deze gevolgtrekking in de praktijk wel voor. ${ }^{126}$

Men zou kunnen zeggen dat door die sanctie spanning ontstaat tussen het waarheidsbeginsel en de eis van proceseffi-

120. Zie bijv. Rb. Den Haag 18 december 2019, ECLI:NL:RBDHA: 2019:14305, r.o. 2.6-2.8.

121. Zie bijv. Rb. Amsterdam (ktr.) 29 oktober 2019, ECLI:NL:RBAMS: 2019:7988

122. HR 15 september 2017, ECLI:NL:HR:2017:2360, r.o. 4.3.2; Hof Arnhem-Leeuwarden (zittingsplaats Arnhem) 27 augustus 2019, ECLI:NL:GHARL:2019:8334, r.o. 2.5.

123. Rb. Rotterdam 8 april 2012, ECLI:NL:RBROT:2012:BW4693.

124. HR 25 april 2008, ECLI:NL:HR:2008:BC2800, NJ 2008/553, m.nt. H.J. Snijders, r.o. 3.3.3; HR 19 juni 2009, ECLI:NL:HR:2009:BI8771, NJ 2010/154, m.nt. H.J. Snijders, r.o. 2.4.4.

125. HR 8 mei 2015, ECLI:NL:HR:2015:1224, JBPr 2015/60, m.nt. H.W Wiersma en NJ2016/218, m.nt. H.J. Snijders.

126. Zie o.m. Hof Amsterdam 20 oktober 2019, ECLI:NL:GHAMS: 2019:3879, r.o. 3.6 en 3.7; Rb. Zwolle (ktr. Deventer) 20 februari 2003 , ECLI:NL:RBZWO:2003:AN4512, r.o. 3 en 4; Rb. Oost-Brabant (zittingsplaats 's-Hertogenbosch) 10 oktober 2018, ECLI:NL:RBOBR: 2018:5062, r.o. 2.10; GEA Curaçao 15 oktober 2018, ECLI:NL:OGEAC:2018:250, r.o. 2.11 ciëntie en/of de eis van de redelijke termijn; men zou het ook kunnen zien als het zoeken van de voor dat geval optimale balans tussen verschillende beginselen van procesrecht. Hierbij weegt mee dat een op onwaarheid gebaseerde uitspraak soms alsnog in een nieuwe procedure kan worden bestreden, ofwel direct via herroeping op grond van art. $382 \mathrm{Rv}$, ofwel in het familierecht via een (nieuw) verzoek tot wijziging van de eerder op grond van de onjuiste informatie vastgestelde regeling, ${ }^{127}$ dan wel indirect via een vordering uit hoofde van onrechtmatige daad. ${ }^{128}$ In die gevallen is het toelaten van een eiswijziging in een lopende procedure efficiënter dan dit op het eerste gezicht lijkt. Verder gelden ook na een schending van de waarheidsplicht door de wederpartij de gebruikelijke beperkingen dat het aanvoeren van nieuwe feiten en/of het wijzigen van de (gronden van de) eis slechts mogelijk zijn indien de procedure nog niet in staat van wijzen is en de partij de onjuistheid niet eerder had kunnen ontdekken. ${ }^{129}$

Ook bij vorderingen en verzoeken om schorsing van de uitvoerbaarheid bij voorraad van de uitspraak kunnen schendingen van de waarheidsplicht meewegen: wanneer blijkt dat de rechter relevante feiten niet in aanmerking heeft kunnen nemen doordat die feiten wegens schending van de waarheidsplicht pas na zijn beslissing blijken, kan dit rechtvaardigen dat van die eerdere beslissing wordt afgeweken. ${ }^{130}$ Zo schorste de kantonrechter te Maastricht de werking van een ontruimingsvonnis wegens een niet moedwillige, maar wel onzorgvuldige schending van de waarheidsplicht door de verhuurder. ${ }^{131} \mathrm{Het}$ gerechtshof Arnhem-Leeuwarden schorste een uitvoerbaar bij voorraad verklaard vonnis wegens schending van de waarheidsplicht in samenhang met het onvoldoende gemotiveerd weerspreken van het restitutierisico. ${ }^{132}$

In opheffingskortgedingen is schending van de waarheidsplicht in het beslagrekest regelmatig aanleiding voor opheffing

127. Zie o.m. HR 12 september 1997, ECLI:NL:HR:1997:ZC2429, NJ 1997/733; HR 14 september 2007, ECLI:NL:HR:2007:BB3554, NJ 2007/485; Wortmann, in: GS Personen- en familierecht, art. 1:401 BW, aant. 3 .

128. Vgl. Van der Wiel 2004, par. 2.2.8.

129. Art. 382 aanhef en onder c Rv; HR 18 mei 2018, ECLI:NL:HR: 2018:727, JBPr 2018/57, m.nt. C.J.M. Klaassen; P.F.J. Lock, 'Ambtshalve rechtstoepassing tijdens de mondelinge behandeling', in: G. de Groot \& H. Steenberghe (red.), De mondelinge behandeling in civiele zaken, Den Haag: Boom juridisch 2019, par. 7.7.4.

130. Zie het overzichtsarrest HR 20 december 2019, ECLI:NL:HR: 2019:2026, $R v d W 2020 / 88$, m.n. r.o. 5.4.4.

131. Rb. Maastricht (vzr.) 26 juni 2003, ECLI:NL:RBMAA:2003:AI6157, r.o. 3.5-3.7.

132. Hof Arnhem-Leeuwarden (zittingsplaats Arnhem) 28 april 2015, ECLI:NL:GHARL:2015:3112, r.o. 3.10 en 3.12. Vgl. Hof ArnhemLeeuwarden (zittingsplaats Leeuwarden) 4 juni 2013, ECLI:NL:GHARL:2013:CA2252, r.o. 6.8 en 6.9. 
van het beslag, ${ }^{133}$ al zijn ook hier verschillen tussen rechters zichtbaar. Sommige rechters laten het principe van waarheidsgetrouwe voorlichting vanwege het ex parte-karakter van beslagen zwaar wegen en sanctioneren schendingen van het waarheidsbeginsel reeds daarom met opheffing van het beslag ${ }^{134}$ - ook als geen sprake is van moedwillige misleiding. ${ }^{135} \mathrm{Als}$ informatie ontbreekt op grond waarvan de rechter het verzoek zou kunnen hebben afgewezen, aan het gegeven bevel andere voorwaarden zou hebben verbonden of partijen zou hebben willen horen alvorens te beslissen, lijkt mij dit juist: ${ }^{136}$ voor een goede rechtsbedeling moet de rechter kunnen vertrouwen op de informatie die hij in beslagrekesten krijgt voorgehouden; ook kan hij de onderliggende rechtsverhouding en de proportionaliteit en subsidiariteit van de gevraagde voorziening niet toetsen als niet alle wezenlijke informatie op tafel ligt. Andere rechters laten het echter bij de constatering van de schending en komen vervolgens na de gebruikelijke belangenafweging alsnog tot handhaving van het beslag. ${ }^{137}$ Mede gezien de openingsalinea van de Beslagsyllabus en het grote belang van een goede voorlichting van de rechter in exparte-gedingen lijkt het opleggen van enige sanctie wel aangewezen, als niet door integrale afwijzing, dan toch via de proceskostenveroordeling of door matiging c.q. gedeeltelijke afwijzing na de belangenafweging. ${ }^{138}$

Wanneer een schending van de waarheidsplicht pas bekend wordt nadat de uitspraak kracht van gewijsde heeft gekregen, rest alleen herroeping (art. $382 \mathrm{Rv}$ ), om de uitspraak van tafel

133. Zie o.m. Hof Amsterdam 21 mei 2019, ECLI:NL:GHAMS:2019:1815, r.o. 3.3; Rb. Overijssel (vzr. Almelo) 28 augustus 2014, ECLI:NL:RBOVE:2014:4669, r.o. 4.5; Rb. Rotterdam (vzr.) 12 oktober 2015 , ECLI:NL:RBROT:2015:7636, r.o. 5.9, 5.10, 5.14 en 5.21; Rb. Amsterdam (vzr.) 15 maart 2016, ECLI:NL:RBAMS:2016:2019, r.o. 4.6; Rb Overijssel (vzr. Zwolle) 26 april 2019, ECLI:NL:RBOVE:2019:1462, r.o. 4.4 en 4.6. Zie over art. $21 \mathrm{Rv}$ in ex parte-gedingen nader mijn noot bij Rb. Den Haag 23 september 2015, ECLI:NL:RBDHA:2015:11490, IER 2016/11, m.n. par. 3 en 4.

134. Rb. Haarlem (vzr.) 29 juli 2011, ECLI:NL:RBHAA:2011:BR3950, r.o. 1.5; Hof Amsterdam 10 januari 2012, ECLI:NL:GHAMS 2012:BV0477, r.o. 2.6; Rb. Midden-Nederland (vzr. Utrecht) 14 oktober 2019, ECLI:NL:RBMNE:2019:5114, r.o. 4.13 en 4.22-4.25.

135. Zie o.m. Rb. Haarlem (vzr.) 10 juli 2009, ECLI:NL:RBHAA: 2009:BJ3022, r.o. 4.6; Hof Amsterdam 22 november 2011 ECLI:NL:GHAMS:2011:BV7108, r.o. 2.4; Rb. Overijssel (vzr. Zwolle) 26 april 2019, ECLI:NL:RBOVE:2019:1462, r.o. 4.4 en 4.6.

136. Vgl. Rb. Den Haag (vzr.) 31 augustus 2018, ECLI:NL:RBDHA 2018:10449, r.o. 4.4; M.R. van Zanten in zijn noot bij Hof Amsterdam 22 november 2011, ECLI:NL:GHAMS:2011:BV7108, JBPr 2012/52; P. de Bruin, 'Enkele bespiegelingen over de waarheidsplicht in het con servatoir beslagrecht', in: S.J.W. van der Putten \& M.R. van Zanten (red.), Compendium beslag-en executierecht, Den Haag: Sdu Uitgevers 2018/35. Anders: Asser Procesrecht/Boonekamp 62020/217.

137. Zie bijv. Hof Amsterdam 15 januari 2019, ECLI:NL:GHAMS 2019:77, r.o. 3.5; Rb. Rotterdam (vzr.) 1 maart 2019, ECLI:NL:RBROT:2019:1699, r.o. 4.7. Vgl. Rb. Rotterdam (vzr.) 13 juli 2018, ECLI:NL:RBROT:2018:5622, r.o. 4.20.

138. Vgl. Rb. Rotterdam (vzr.) 27 augustus 2018, ECLI:NL:RBROT: 2018:8151, r.o. 3.6-3.8; GEA Sint Maarten 13 september 2019 ECLI:NL:OGEAM:2019:95, r.o. 4.11 en noot 6, verwijzend naar Rb. Overijssel 17 augustus 2017, ECLI:NL:RBOVE:2017:3355 (waar de schending mijns inziens te zwaar was); Rb. Midden-Nederland (vzr. Utrecht) 14 oktober 2019, ECLI:NL:RBMNE:2019:5114, r.o. 4.25. te krijgen, ${ }^{139}$ of een executieverbod wegens misbruik van procesrecht, om de gevolgen ervan te beperken. Als aan de eisen van art. $382 \mathrm{Rv}$ niet wordt voldaan, kan het materiële recht uitkomst bieden indien de schending van de waarheidsplicht een onrechtmatige daad oplevert op grond waarvan de dader schadeplichtig is; ${ }^{140}$ in die gevallen zal schadevergoeding in natura soms uitkomst bieden.

\subsubsection{Afwijking van de herkansingsfunctie van het appel}

In Nederland heeft het hoger beroep een herkansingsfunctie: men mag zijn in eerste aanleg gemaakte fouten corrigeren en de vordering met nieuwe stellingen en rechtsgronden onderbouwen - ook als men die al in eerste aanleg had kunnen aanvoeren. ${ }^{141}$ Echter: wanneer nieuwe standpunten gebaseerd zijn op gegevens die in vorige instantie al bekend én relevant waren, was het achterhouden ervan in eerste aanleg in strijd met art. $21 \mathrm{Rv}$ - en als de rechter om die gegevens heeft gevraagd: ook met art. $22 \mathrm{Rv}$. Wanneer de in eerste aanleg ontbrekende informatie in appel alsnog wordt gegeven, wordt soms maar weinig aandacht besteed aan klachten over de schending van de waarheidsplicht. ${ }^{142}$ In andere uitspraken worden juist de waarheidsplicht, de processuele kosten van schendingen daarvan en/of het belang van beslissen op grond van de waarheid vooropgesteld. ${ }^{143}$ Onduidelijk blijft of dit verschil in aanpak steeds voortkomt uit een verschil in rechtsopvatting van de raadsheren in de combinatie, of uit verschillen in de onderliggende dossiers (zoals de kwaliteit van de grieven en de onderbouwing daarvan). Wanneer de waarheidsplicht zowel in eerste aanleg als in appel is geschonden, zien alle hoven aanleiding tot oplegging van een sanctie. ${ }^{144}$

Overigens worden de in eerste aanleg wegens laakbaar procesgedrag opgelegde sancties doorgaans in stand gelaten: de herkansingsfunctie van het hoger beroep beperkt zich tot het in

139. Zie bijv. Hof Den Haag 8 januari 2020, ECLI:NL:GHDHA:2020:44, r.o. 5.5; Hof Arnhem-Leeuwarden (zittingsplaats Arnhem) 18 februari 2020, ECLI:NL:GHARL:2020:1368, m.n. r.o. 2.17.

140. Zie bijv. Hof 's-Hertogenbosch 21 januari 2020, ECLI:NL:GHSHE: 2020:171.

141. Vaste rechtspraak, zie o.m. HR 20 juni 2008, ECLI:NL:HR 2008:BC4959, NJ 2009/21 (Willemsen/NOM), r.o. 4.2.3; HR 19 juli 2019, ECLI:NL:HR:2019:1234, RvdW 2019/913, r.o. 3.1.3.

142. Zie bijv. Hof Den Haag 19 juni 2019, ECLI:NL:GHDHA:2019:2399, m.n. r.o. 5.16 en 5.19 .

143. Hof Amsterdam 10 september 2019, ECLI:NL:GHAMS:2019:3349, r.o. 5.8; Hof Amsterdam 29 oktober 2019, ECLI:NL:GHAMS: 2019:3879, r.o. 3.7. Vgl. Hof 's-Gravenhage 7 november 2007, ECLI:NL:GHSGR:2007:BC0157, r.o. 6 en 7; Hof Arnhem-Leeuwarden (zittingsplaats Arnhem) 27 augustus 2019, ECLI:NL:GHARL: 2019:8334, r.o. 2.4 en 2.5; Hof 's-Hertogenbosch 12 september 2019, ECLI:NL:GHSHE:2019:3344, r.o. 3.4.5 en 3.5.

144. Zie o.m. Hof Den Haag 15 november 2016, ECLI:NL:GHDHA: 2016:3305, r.o. 2.2; Hof Arnhem-Leeuwarden (zittingsplaats Leeuwarden) 21 augustus 2018, ECLI:NL:GHARL:2018:7647, r.o. 2.16; Hof 's-Hertogenbosch 6 juni 2019, ECLI:NL:GHSHE:2019:2038, r.o. 5.21.3-5.22; Hof Amsterdam 10 september 2019, ECLI:NL:GHAMS: 2019:3349, r.o. 5.7 en 5.8; Hof Den Haag 8 oktober 2019, ECLI:NL:GHDHA:2019:3289, r.o. 38. 
appel opnieuw uiteen mogen zetten van de zaak. ${ }^{145}$ Zelfs op die hoofdregel kan echter een uitzondering worden gemaakt. Zo overwoog het gerechtshof Amsterdam in een arrest van 29 oktober 2019 (waartegen cassatie is ingesteld):

'De herstelfunctie van het hoger beroep gaat daarbij niet zover dat een partij, die in eerste aanleg weloverwogen en doelbewust relevante informatie achterhoudt om ten koste van haar wederpartij een schadevergoeding toegewezen te krijgen, de gelegenheid zou moeten krijgen om na ontdekking daarvan haar vorderingen ter zake aan te passen. Een andersluidend oordeel zou er ook toe leiden dat partijen in feite risicoloos, zonder enige belemmering of sanctie (voor de beoordeling van het geschil relevante) onwaarheden zouden kunnen debiteren en ook ongestraft de rechter op het verkeerde been zouden mogen zetten.' ${ }^{146}$

In deze procedure had de kantonrechter gevolgtrekkingen gemaakt die neerkomen op uitzonderingen op de leer van de bindende eindbeslissing. Het door het hof beschreven procesgedrag komt neer op misbruik van procesrecht; zijn oordeel komt er dan op neer dat misbruik van procesrecht (een onrechtmatige daad ${ }^{147}$ ) niet kan worden hersteld. ${ }^{148}$ Deze gevolgtrekking komt neer op een beperking van de herkansingsfunctie van het appel - een benadering die mijns inziens past bij de sinds 2002 ingezette ontwikkeling in ons procesrecht dat van procespartijen steeds meer wordt verlangd dat zij verantwoordelijkheid aanvaarden voor een ordelijk, voorspoedig én eerlijk verloop van de procedure. ${ }^{149}$

Van het arrest is overigens cassatieberoep ingesteld. ${ }^{150}$ Zelfs als de Hoge Raad het cassatieberoep onverhoopt zou afdoen met art. 81 Wet RO, verwacht ik dat het arrest - in samenhang met de conclusie - nuttige handvatten zal bieden voor een proportionele sanctionering van de waarheidsplicht.

\subsection{Schatting door de rechter}

In zaken waarin schadevergoeding wordt gevorderd, sanctioneert de rechter schendingen van de waarheidsplicht soms door zonder nadere proceshandelingen over te gaan tot het conform art. 6:97 BW schatten van de schade, waarbij hij onduidelijkheden voor risico laat van de partij die de op haar

145. Zie voor een sanctie die neerkwam op een verslechterde bewijspositie: Hof Arnhem 27 juli 2004, ECLI:NL:GHARN:2004:AR4652, r.o. 4.4-4.6.

146. Hof Amsterdam 29 oktober 2019, ECLI:NL:GHAMS:2019:3879, r.o. 3.7. Vgl. Rb. Roermond 28 november 2007, ECLI:NL:RBROE: 2007:BC0427, r.o. 4.5-4.7; Rb. Midden-Nederland (vzr. Utrecht) 14 oktober 2019, ECLI:NL:RBMNE:2019:5114, r.o. 4.25 .

147. HR 24 juni 2016, ECLI:NL:HR:2016:1290, JBPr 2016/51, m.nt J.D.A. den Tonkelaar, r.o. 3.6.3; Hof Amsterdam 3 december 2019, ECLI:NL:GHAMS:2019:4307, r.o. 3.31.

148. Vgl. in het bestuursrecht HR 10 december 2010, ECLI:NL:HR: 2010:BO6786, JB 2011/21, m.nt. A.J. Bok, r.o. 3.1.

149. Kamerstukken II 2000/01, 26855, nr. 16, p. 17-19; minister Korthals bij de voortgezette behandeling van de wetsvoorstellen inzake Rechterlijke organisatie/Raad voor de rechtspraak/Procesrecht d.d. 4 december 2001, Handelingen I 2001/02, nr. 10-507.

150. Zaaknr. 20/00302. rustende waarheidsplicht heeft geschonden. ${ }^{151}$ In familiezaken kan de rechter volgens vaste jurisprudentie een soortgelijke benadering hanteren als een partij onvoldoende inzicht geeft in haar financiële situatie. ${ }^{152}$

\subsection{Meewegen in belangenafweging}

Soms maken schendingen van de waarheidsplicht deel uit van een opsomming van omstandigheden die de rechter heeft meegewogen in een belangenafweging en/of wordt het als nevengeschikt argument genoemd: 'Gelet op deze feiten en omstandigheden en tegen de achtergrond van (...) artikel 21 Rv.' ${ }^{\prime 53}$ Het gedrag dat de schending van de waarheidsplicht vormt, wordt dan bijvoorbeeld meegewogen bij de inschatting of de betrokken partij vrijwillig zal meewerken bij overeengekomen of bevolen vervolgstappen. ${ }^{154}$ Ook komt het voor dat de schending negatieve gevolgen heeft gehad, welke gevolgen dan als omstandigheden extra gewicht in de schaal leggen ten voordele van de wederpartij. ${ }^{155}$ Verder kunnen schendingen van de waarheidsplicht meewegen bij het aanvangstijdstip van de korte verjaringstermijn, welk tijdstip mede door de billijkheid wordt bepaald, ${ }^{156}$ en de vervaltermijn van drie maanden voor het instellen van een herroepingsvordering. ${ }^{157}$

\subsection{Toewijzen verzocht dwangmiddel}

Wanneer gedurende het geding blijkt dat een van partijen informatie achterhoudt, draagt dit bij aan het vermoeden dat zij een voor haar nadelige beslissing niet vrijwillig en te goeder trouw zal naleven. Schending van de waarheidsplicht wordt daarom door rechters wel meegewogen bij de beoordeling van de vraag of er aanleiding is een dwangmiddel op te leggen ${ }^{158}$ - vooral wanneer de beslissing inhoudt dat de partij informatie moet verschaffen of een kopie van het vonnis aan

151. Zie bijv. Rb. Den Haag 11 september 2019, ECLI:NL:RBDHA: 2019:10653, r.o. 5.6-5.11. Vgl. begroting bij beslag Rb. Rotterdam (vzr.) 28 maart 2013, ECLI:NL:RBROT:2013:BZ6869, r.o. 4.2 en 4.13.

152. HR 25 maart 2011, ECLI:NL:HR:2011:BO9675, r.o. 3.5.2; HR 13 juli 2012, ECLI:NL:HR:2012:BX1295, NJ 2012/498, m.nt. S.F.M. Wortmann, r.o. 3.4.2.

153. Rb. Maastricht (vzr.) 26 juni 2003, ECLI:NL:RBMAA:2003:AI6157, r.o. 3.5-3.7; Rb. Rotterdam (vzr.) 13 juli 2018, ECLI:NL:RBROT: 2018:7043, r.o. 5.6; Rb. Rotterdam (vzr.) 21 februari 2020, ECLI:NL:RBROT:2020:2302, r.o. 4.13. Vgl. Hof 's-Hertogenbosch 4 februari 2020, ECLI:NL:GHSHE:2020:340, r.o. 3.4.10.

154. Rb. Rotterdam (vzr.) 27 augustus 2018, ECLI:NL:RBROT:2018:7129, r.o. 4.1.

155. Rb. Roermond (vzr.) 26 mei 2008, ECLI:NL:RBROE:2008:BD2900, r.o. 4.5.

156. Hof 's-Hertogenbosch 7 maart 2017, ECLI:NL:GHSHE:2017:890, JA 2017/75, r.o. 6.30-6.33 onder verwijzing naar HR 31 oktober 2003, ECLI:NL:HR:2003:AL8168.

157. Hof Arnhem-Leeuwarden (zittingsplaats Arnhem) 26 november 2019, ECLI:NL:GHARL:2019:10166, r.o. 4.5 (slot).

158. Rb. Haarlem (vzr.) 13 juli 2011, ECLI:NL:RBHAA:2011:BR3952, r.o. 5.7; Rb. Rotterdam (vzr.) 28 maart 2013, ECLI:NL:RBROT: 2013:BZ6869, r.o. 4.2 en 4.13; Rb. Den Haag (vzr.) 12 juli 2016, ECLI:NL:RBDHA:2016:7891, r.o. 4.8; Hof 's-Hertogenbosch 12 september 2019, ECLI:NL:GHSHE:2019:3344, r.o. 3.4.5. 
opvolgende beslagrekesten moet aanhechten. ${ }^{159}$ Meningsverschil bestaat nog over de vraag of art. $21 \mathrm{Rv}$ een voldoende grondslag biedt voor de oplegging van een (gevorderde) dwangsom; gezien de ongeclausuleerde formulering en fundamentele aard van deze wettelijke bepaling zou ik denken van wel. ${ }^{160}$ Waar de wetgever aan een wettelijke plicht tot het verschaffen van informatie geen sanctie verbindt, zoals in art. 4:78 BW, wordt het opleggen van een dwangsom een bijna noodzakelijk instrument om de informatie op tafel te krijgen. ${ }^{161}$ Art. $843 \mathrm{a}$ Rv ziet immers alleen op reeds bestaande documenten en niet op documenten die nog moet worden opgesteld.

\subsection{Proceskostenveroordeling}

In 2014 constateerde ik dat rechters weinig gebruik maakten van de mogelijkheid om schendingen van de waarheidsplicht via de proceskosten te sanctioneren, maar dat is inmiddels wel anders. Zowel het opzettelijk als het verwijtbaar te laat inbrengen van (ware) relevante informatie wordt inmiddels regelmatig bestraft met het (gedeeltelijk) toe- of afwijzen van proceskosten. ${ }^{162}$ Dat zal mede te maken hebben met het feit dat advocaten de sanctie hebben ontdekt: in veel zaken verzoeken zij specifiek om oplegging van die sanctie, liefst om toewijzing van de werkelijke proceskosten.

De werkelijke proceskosten worden echter alleen toegewezen waar het procesgedrag neerkomt op misbruik van procesrecht. Daarvan is niet snel sprake, zelfs niet indien de betrokken partij haar vordering in twee instanties onvoldoende onderbouwt. ${ }^{163}$ Voor misbruik van recht is vereist dat rechten zo evident worden ingeroepen zonder enig redelijk doel of voor een ander doel dan waarvoor zij zijn gegeven, dan wel op een wijze die zo disproportioneel is ten opzichte van het gestelde/mogelijke doel, dat dit blijk geeft van kwade trouw. Gelet op het fundamentele recht op toegang tot de rechter is daarvan in het procesrecht pas sprake als het instellen van de vordering of het voeren van verweer, gelet op de evidente ongegrondheid ervan, ${ }^{164}$ in verband met de betrokken belangen van de wederpartij achterwege had behoren te blijven. Hiervan is sprake als een partij haar vordering of verweer baseert op feiten en omstandigheden waarvan zij de onjuist-

159. Rb. Arnhem (vzr.) 8 juli 2009, ECLI:NL:RBARN:2009:BJ4432, r.o. 4.9; Rb. Amsterdam (vzr.) 17 maart 2011, ECLI:NL:RBAMS: 2011:BP8070, r.o. 7.6 en 9.6; Rb. Rotterdam (vzr.) 28 maart 2013, ECLI:NL:RBROT:2013:BZ6869, r.o. 4.2 en 4.13; Rb. Amsterdam (vzr.) 23 januari 2018, ECLI:NL:RBAMS:2018:1791, r.o. 5.8 en 7.2.

160. Anders: Hof Amsterdam (vzr.) 26 mei 2009, ECLI:NL:GHAMS: 2009:BO3202, r.o. 5.5 .

161. Vgl. de wenk bij Hof 's-Hertogenbosch 12 september 2019, ECLI:NL:GHSHE:2019:3344, RN 2019/95.

162. Zie bijv. Rb. Noord-Holland (ktr. Alkmaar) 10 februari 2016, ECLI:NL:RBNHO:2016:898, r.o. 5.16; Rb. Noord-Holland (ktr. Alkmaar) 17 april 2019, ECLI:NL:RBNHO:2019:3365, r.o. 1.4; Rb. Midden-Nederland (ktr. Utrecht) 23 oktober 2019, ECLI:NL:RBMNE: 2019:4917, r.o. 2.22.

163. HR 5 februari 2016, ECLI:NL:HR:2016:198, r.o. 3.4.3 en 3.4.4.

164. T. van Malssen benadrukt dat de evidente ongegrondheid van de vordering c.q. het verweer uit de motivering moet blijken, zie zijn noot bij Rb. Noord-Holland (ktr. Alkmaar) 26 juni 2019, ECLI:NL:RBNHO:2019:5923, $J B \operatorname{Pr} 2020 / 11$, par. 15. heid kende dan wel behoorde te kennen, of op stellingen waarvan zij op voorhand moest begrijpen dat deze geen kans van slagen hadden. ${ }^{165}$

De Ondernemingskamer opteert soms voor een middenweg, in die zin dat een hoger of het dubbele liquidatietarief wordt toegewezen. ${ }^{166}$ Een Amsterdamse kantonrechter berekende de proceskostenveroordeling onlangs met een hoger liquidatietarief wegens een schending van de waarheidsplicht die weliswaar geen misbruik van procesrecht vormde, maar wel een zeker gewicht had. ${ }^{167}$ Dergelijke gevolgtrekkingen staan de rechter vrij: de begroting van proceskosten is een beslissing van feitelijke aard die geen motivering behoeft, en de liquidatie- en indicatietarieven behelzen slechts niet-bindende richtlijnen. ${ }^{168}$

Het voordeel van een financiële sanctie is dat de rechter alsnog gebleken feiten niet buiten beschouwing laat en dus alsnog zoveel mogelijk op basis van de waarheid beslist. Een financiële sanctie voor een in eerste aanleg begane schending kan ook in stand blijven wanneer betrokkene zijn fouten in appel herstelt en alsnog gelijk krijgt; ${ }^{169}$ zo kunnen hoven zowel ongewenst procesgedrag ontmoedigen als rechtdoen op grond van de alsnog gebleken waarheid. Echter, wanneer de proceskosten ten opzichte van het belang van de zaak relatief laag zijn, zou een sanctie in de proceskostensfeer wel oneigenlijke processtrategieën kunnen stimuleren (eerst feiten achterhouden om een zo gunstig mogelijke uitspraak te krijgen, en als dat misloopt in appel een andere strategie proberen). Alleen het toewijzen van (een deel van) de geliquideerde proceskosten en zelfs het toewijzen van de door de schending veroorzaakte werkelijke proceskosten ${ }^{170}$ kunnen ook niet altijd alle door de 'verlate' eerlijkheid c.q. zorgvuldigheid ontstane kosten en vertraging compenseren. Een risico van al te ruimhartige financiële sancties is verder dat de dreiging ervan niet alleen de drempel voor laakbaar procesgedrag, maar ook die voor een gang naar de rechter kan verhogen. Ook bij deze relatief overzichtelijke wijze van sanctioneren zijn proportionaliteit en voorspelbaarheid dus van belang.

\subsection{Doen van aangifte}

Bepaalde vormen van onwaarachtigheid schenden niet alleen de waarheidsplicht, maar voldoen ook aan delictsomschrijvin-

165. HR 6 april 2012, ECLI:NL:HR:2012:BV7828, NJ 2012/233; HR 15 september 2017, ECLI:NL:HR:2017:2360, r.o. 5.3.3 en 5.3.4. Zie recent ook Hof's-Hertogenbosch 31 oktober 2019, ECLI:NL:GHSHE: 2019:4041.

166. Hof Amsterdam (OK) 23 mei 2019, ECLI:NL:GHAMS:2019:1741, r.o. 3.15; Hof Amsterdam (OK) 18 december 2019, ECLI:NL:GHAMS:2019:4532, r.o. 3.13.

167. Rb. Amsterdam (ktr.) 20 januari 2020, ECLI:NL:RBAMS:2020:284, r.o. 13.

168. HR 3 april 1998, ECLI:NL:HR:1998:ZC2621, NJ 1998/571, r.o. 3.3; HR 24 januari 2020, ECLI:NL:HR:2020:112, NJ 2020/59, r.o. 3.3.1.

169. Hof Leeuwarden 6 augustus 2008, ECLI:NL:GHLEE:2008:BD9890, r.o. 8; Hof 's-Hertogenbosch 7 juli 2009, ECLI:NL:GHSHE: 2009:BJ4469, r.o. 4.5.7.

170. Rb. Den Haag (ktr.) 27 november 2019, ECLI:NL:RBDHA: 2019:12635, r.o. 4.19. 
gen uit het Wetboek van Strafrecht, zoals meineed en valsheid in geschrifte. Mag de rechter dan aangifte doen? De Hoge Raad heeft in 2001 in een trits standaardarresten benadrukt dat de openheid in de gedingvoering en daarmee de waarheidsvinding doorgaans juist wordt gediend met het achterwege blijven van een aangifte door de rechter. Wanneer partijen vrezen voor een aangifte (bijvoorbeeld van zwart geld), brengen zij niet vrijelijk alle relevante feiten naar voren. Wanneer echter een partij met valse stukken of verklaringen heeft geprobeerd een eerlijk proces te frustreren door valse informatie in te brengen, staat het de rechter vrij de stukken ten aanzien waarvan bij hem het vermoeden is gerezen dat strafbare feiten zijn gepleegd, aan de officier van justitie voor aangifte door te geleiden. ${ }^{171}$ Een Haagse kantonrechter lijkt daartoe mede te hebben besloten omdat de partij in kwestie hem juist had aangemoedigd aangifte tegen haar wederpartij te doen. ${ }^{172}$

\section{Conclusie}

De wetgever heeft de rechter een ruime bevoegdheid gegeven om de waarheidsplicht te sanctioneren, ter bescherming van zowel de particuliere belangen van wederpartijen als het algemeen maatschappelijk belang dat de waarheid in rechte - tijdig - aan het licht komt. Van die bevoegdheid maakt de rechter steeds vaker en op creatieve wijze gebruik, ambtshalve of op verzoek van een procespartij.

De doelen van de sancties die rechters opleggen, zijn - evenals in 2014 - (a) dat recht wordt gedaan op basis van de waarheid, en (b) dat de kosten van onwenselijk gedrag voor rekening blijven van de verantwoordelijke partij. Is de schending licht en wordt de informatie alsnog verschaft? Dan blijft de gevolgtrekking navenant licht. Toepassing van de waarheidsplicht hoeft dus niet beperkt te blijven tot uitzonderlijke situaties. ${ }^{173}$ Soms lijken sancties mede gericht op generale of individuele preventie, met name jegens repeat players en andere partijen die de waarheidsplicht vaker en/of op grove wijze aan hun laars hebben gelapt. Naar de letter en geest van art. $21 \mathrm{Rv}$ zijn ook die meer punitieve sancties mogelijk; wel vragen zij om een goede motivering, zodat toetsbaar is of de gevolgtrekking strookt met de aard en de ernst van de schending.

$\mathrm{Nu}$ de waarheidsplicht een open norm is, is die motivering echter niet steeds eenvoudig; sanctionering van die norm kost de rechter dan extra 'moeite', terwijl de uitkomst voor partijen niet altijd anders is dan wanneer hij de zaak op de stelplicht of op materiële gronden afdoet. Mogelijk is dat een van de redenen dat rechters de vraag of de waarheidsplicht is geschonden

171. HR 30 oktober 2001, ECLI:NL:HR:2001:ZD2516, ECLI:NL:HR: 2001:ZD2513, ECLI:NL:HR:2001:ZD2514 en ECLI:NL:HR: 2001:ZD2515, NJ 2003/199-202, m.nt. W.D.H. Asser. Zie nader D. Visser, 'Mag de civiele rechter aangifte doen van strafbare feiten die hem ter kennis komen?', Trema 2016, afl. 4, p. 116-124.

172. Rb. Den Haag (ktr.) 27 november 2019, ECLI:NL:RBDHA: 2019:12635, r.o. 4.20.

173. Anders: Rb. Rotterdam (ktr.) 19 december 2019, ECLI:NL:RBROT: 2019:10113, r.o. 4.1. soms liever in het midden laten. ${ }^{174}$ Hoewel begrijpelijk, zou het de met de invoering van art. 21, 22, 111 lid 3 en 128 lid 5 Rv beoogde cultuuromslag (= einde an de 'houd-je-kruitdroog-tactiek ${ }^{175}$ ) op weg kunnen helpen als rechters het achterliggende waarheidsbeginsel benoemen wanneer zij aan de schending daarvan consequenties verbinden. Anders gezegd: waar de rechter van oordeel is dat het niet boven water komen van relevante informatie het gevolg is van toerekenbaar onzorgvuldig procesgedrag, verdient het de voorkeur dat uit zijn uitspraak blijkt dat de uitkomst van het geding (mede) een gevolg is van dat procesgedrag. ${ }^{176}$ Ook daarom is de pilot Consumentenverstekken toe te juichen.

174. Zie bijv. Hof Amsterdam 30 januari 2018, ECLI:NL:GHAMS: 2018:286, r.o. 3.5; Rb. Den Haag (ktr.) 7 november 2019, ECLI:NL:RBDHA:2019:14606, r.o. 3.3 en 5.6; Rb. Amsterdam 12 februari 2020, ECLI:NL:RBAMS:2020:768. Vgl. Ahsmann 2017; W.I. Wisman \& S. Heeroma, 'De mondelinge behandeling in civiele zaken', TCR 2020, afl. 1, p. 13, eerste kolom.

175. Kamerstukken II $1999 / 2000,26855$, B, p. 12; Kamerstukken II 1999/2000, 26855, nr. 3, p. 8; Kamerstukken II 1999/2000, 26855, nr. 5, p. 23; Kamerstukken II 2000/01, 26855, nr. 16, p. 3 en 33; Kamerstukken II 2006/07, 30951, nr. 1, p. 11, par. 26. Zie over de noodzaak voor een cultuurverandering al E.M. Meijers, 'De invloed der praktijk op de vorming van het Nederlandsche procesrecht', $T v R$ 1918, p. 169.

176. Zie bijv. Rb. Midden-Nederland (zittingsplaats Lelystad) 29 januari 2019, ECLI:NL:RBMNE:2019:443, r.o. 4.1-4.2.5; Hof 's-Hertogenbosch 26 november 2019, ECLI:NL:GHSHE:2019:4331, r.o. 12.8; Rb. Amsterdam (ktr.) 9 december 2019, ECLI:NL:RBAMS:2019:9049; Rb. Den Haag 18 december 2019, ECLI:NL:RBDHA:2019:14305, r.o. 2.6-2.8; Rb. Noord-Holland (ktr. Haarlem) 18 maart 2020, ECLI:NL:RBNHO:2020:1976, r.o. 5.16. Vgl. M.J.A.M. Ahsmann, De weg naar het civiele vonnis, Den Haag: Boom Juridische uitgevers 2011, p. 183-184. 